\title{
Instantaneous Effects of Sediment Resuspension on Inorganic and Organic Benthic Nutrient Fluxes at a Shallow Water Coastal Site in the Gulf of Finland, Baltic Sea
}

\author{
Juha Niemistö ${ }^{1}$ (D) $\cdot$ Lars Chresten Lund-Hansen ${ }^{2}$ \\ Received: 7 February 2019 /Revised: 23 August 2019 / Accepted: 23 September 2019 / Published online: 31 October 2019 \\ (C) The Author(s) 2019
}

\begin{abstract}
Climate change is leading to harsher resuspension events in shallow coastal environments influencing benthic nutrient fluxes. However, we lack information on the quantitative connection between these fluxes and the physical forces. Two identical experiments that were carried out both in May and August provided novel knowledge on the instantaneous effects of resuspension with known intensity on the benthic dissolved inorganic (phosphate: DIP, ammonium: $\mathrm{NH}_{4}{ }^{+}$, nitrite+nitrate: $\mathrm{NO}_{x}$, silicate, DSi) and organic nutrient (phosphorus: DOP, nitrogen: DON, carbon: DOC) fluxes in the shallow soft bottoms of the archipelago of Gulf of Finland (GoF), Baltic Sea. Resuspension treatments, as 2 times the critical shear stress, induced effluxes of one to two orders of magnitude higher than the diffusive fluxes from the studied oxic bottoms. The presence of oxygen resulted in newly formed iron oxyhydroxides and the subsequent precipitation/ adsorption of the redox-dependent nutrients (DIP, DSi, organic nutrients) affecting their fluxes. Resuspension-induced $\mathrm{NH}_{4}{ }^{+}$and $\mathrm{NO}_{x}$ fluxes were associated with the organic content of sediments showing the highest values at the organic rich sites. $\mathrm{NH}_{4}{ }^{+}$showed the strongest responses to resuspension treatments in August, but $\mathrm{NO}_{x}$ at the time of high oxygen concentrations in near-bottom water in May. Foreseen increases in the frequency and intensity of resuspension events due to climate change will most likely enhance the internal nutrient loading of the studied coastal areas. The fluxes presented here, connected to known current velocities, can be utilized in modeling work and to assess and predict the internal nutrient loading following climate change.
\end{abstract}

Keywords Sediment resuspension $\cdot$ Benthic flux $\cdot$ Inorganic and organic nutrients $\cdot$ Critical shear stress

Communicated by Marco Bartoli

Electronic supplementary material The online version of this article (https://doi.org/10.1007/s12237-019-00648-5) contains supplementary material, which is available to authorized users.

Juha Niemistö

juha.niemisto@helsinki.fi

Lars Chresten Lund-Hansen

lund-hansen@bios.au.dk

1 Ecosystems and Environment Research Programme, Faculty of Biological and Environmental Sciences, P.O. Box 65, (Viikinkaari 1), FI-00014 Helsinki, Finland

2 Arctic Research Centre, Department of Bioscience, Aarhus University, Build. 1540, Ny Munkegade 114, 8000 Aarhus C, Denmark

\section{Introduction}

Shallow coastal areas function as buffer zones for nutrients entering a marine ecosystem from its catchment. Sediment resuspension caused by surface waves and near-bottom currents is a common phenomenon that has implications on mineralization and recycling of benthic nutrients of shallow coastal areas (e.g., Sloth et al. 1996; Thomsen et al. 2002; Ståhlberg et al. 2006; Capet et al. 2016). Altered nutrient recycling may in turn affect the productivity of overlying waters (e.g., Fanning et al. 1982; Porter et al. 2010). Although the different effects of resuspension on nutrient cycling in the coastal areas have been studied, the quantification of the effects of sediment resuspension on sediment-water fluxes needs additional attention, since shallow area sediments supply significant amounts of limiting nutrients to primary producers globally (Boynton et al. 2018). 
Resuspension occurs when a critical shear stress, a force needed to initiate movement of surface sediment particles, is exceeded (e.g., Sheng and Lick 1979). In future, resuspension events are foreseen to occur more frequently and to be stronger in the marine shallow coastal areas including those of the Baltic Sea (Räisänen et al. 2004; Danielsson et al. 2007). Due to increased wind activity and possible change in the direction of prevailing winds, most critical impacts may occur in areas where the bottom sediments are currently more or less sheltered (Danielsson et al. 2007) and even minor strengthening of winds may markedly increase resuspension in shallow areas (Jönsson 2005). This is especially relevant for the shallow Baltic Sea where $25 \%$ of the total area is shallower than 20 $\mathrm{m}$, and for its strongly eutrophied sub-basin, Gulf of Finland (GoF) (mean depth $38 \mathrm{~m}$ ) (e.g., Andersen et al. 2015). Additionally, climate change is expected to increase the external nutrient loading from the catchment areas to the estuarine and coastal areas of the Baltic Sea due to increased annual and especially winter runoff and shortened snow cover period (Schneider et al. 2013; Huttunen et al. 2015). This emphasizes the crucial roles of the physical and chemical processes affecting the cycling of nutrients between sediment and water in coastal areas. Therefore, it is important to gain knowledge of the current prerequisites for sediment resuspension as well as the effects of sediment disturbance on benthic nutrient cycling. Such knowledge is valuable e.g. for different model assessments used for predicting internal nutrient loadings in the shallow coastal areas of the Baltic Sea in a changing climate.

GoF has a wide, fragmented archipelago on its northern shore (Winterhalter et al. 1981; Virtasalo et al. 2005; Jilbert et al. 2017). The archipelago's geographical complex shape and varying bathymetry together with physical forces, waves, and currents have created a mosaic like bottom sediment showing great spatial differences in water and organic content and grain sizes. Shallow bottoms of the archipelago differ in susceptibility to sediment resuspension depending on the direction and velocity of winds that create surface waves, water currents, and upwelling events, which drive resuspension (e.g., Haapala 1994). In the GoF archipelago, as in other shallow water areas of the Baltic Sea, sediment resuspension has been shown to affect the benthic nutrient fluxes as well as being responsible for the flux of sediment-bound main nutrients (such as carbon, nitrogen, and phosphorus) from shallow to deeper waters (Floderus and Håkanson 1989; Christiansen et al. 1992; Heiskanen et al. 1998; Niemistö et al. 2018). Consequently, the susceptibility of sediments for resuspension and the nutrient retention capacity of sediments influence the magnitude of internal loading and fluxes of nutrients into the water column and to the deeper basins of the Baltic Sea (Christiansen and Emelyanov 1995).

Benthic dynamics of some inorganic nutrients, such as dissolved inorganic phosphorus (DIP) and dissolved silicate
$\left(\mathrm{Si}(\mathrm{OH})_{4}\right.$, hereafter $\left.\mathrm{DSi}\right)$, depends on the physico-chemical conditions (redox potential, sorption-desorption reactions) at the sediment-water interface, in which resuspension may induce changes. Resuspension-induced oxygenation of surface sediments produces iron oxyhydroxides, which can bound DIP and DSi (Anderson and Benjamin 1985; Pant and Reddy 2001; Sundby et al. 1986; Niemistö et al. 2018). Additionally, resuspension affects the sorption-desorption reactions on particle surfaces by altering the nutrient concentrations in the ambient solution (Koski-Vähälä and Hartikainen 2000; Tallberg et al. 2008). Dissolved organic nutrients also strongly associate with particles in coastal waters (Asmala et al. 2014; Jilbert et al. 2017). Their benthic fluxes may be affected by resuspension-produced iron oxyhydroxides that can efficiently adsorb these nutrients (Dzombak and Morel 1990; Eusterhues et al. 2008; Skoog and Arias-Esquivel 2009). Benthic fluxes of ammonium $\left(\mathrm{NH}_{4}{ }^{+}\right)$and nitrite+nitrate $\left(\mathrm{NO}_{x}\right)$ can be altered due to resuspension (Spagnoli and Bergamini 1997; Morin and Morse 1999; Niemistö et al. 2018). This is because microbial-mediated transformation pathways of nitrogen either require the presence (nitrification) or absence (denitrification) of oxygen (e.g., Thamdrup and Dalsgaard 2008), whose benthic fluxes may be affected by resuspension (Almroth et al. 2009; AlmrothRosell et al. 2012; Moriarty et al. 2017; Niemistö et al. 2018). Although resuspension evidently alters the benthic nutrient fluxes in the Baltic Sea (e.g., Almroth et al. 2009; AlmrothRosell et al. 2012; Niemistö et al. 2018), there is a lack of knowledge on the exact critical forces and water current velocities that initiate these resuspension events, as well as on the quantitative connection between water current velocities and the magnitude of benthic fluxes in an archipelago area.

This study was conducted in the archipelago of the GoF, Baltic Sea, in fairly sheltered soft sediments which encounter episodic resuspension events in the present climatic conditions. The sediments that vary in water and organic content were studied to determine the critical shear stresses and the instantaneous effects of resuspension on benthic nutrient fluxes. The resuspension induced with known force was hypothesized to significantly increase the benthic fluxes of inorganic and organic nutrients to the water column, and thus their supply for primary producers during the pelagic productive season.

\section{Material and Methods}

\section{Study Area}

The study was conducted in the archipelago of Gulf of Finland near the Hanko Peninsula. Rapid displacements of various water masses caused by fluctuations in meteorological conditions are common in the study area and due to this, the area is 
influenced by the surface water with different salinities (Gulf of Finland: salinity 5-6 practical salinity units (psu); inner archipelago: 3-5 psu; upwelling deep water: 7 psu) (Niemi 1975). Four stations were sampled over two seasons, spring and summer, to cover the important periods for pelagic production. Three of the study stations (1-3) were located in the semi-enclosed bay Storfjärden and the fourth station (4) was located on the outer edge of the archipelago (Fig. 1). All the study stations were fairly sheltered from the prevailing southwestern winds. The stations that differed in depth were chosen to cover bottom areas with different sediment characteristics (e.g., grain size, water, and organic content) with oxygen present in the bottom water (in situ measurements $0.5 \mathrm{~m}$ above the bottom) through the productive season (Tables 1 and 2).

\section{Experimental Design}

\section{Sediment Sampling and Critical Shear Stress Measurements}

From each station, undisturbed sediment cores were collected with an HTH gravity corer (Pylonex, Umeå, Sweden, inner diameter $86 \mathrm{~mm}$ ) (Renberg and Hansson 2008). The samples were moved to the experimental columns of the LABEREX chamber at the field (transparent polycarbonate core, height 30 $\mathrm{cm}$, inner diameter $84 \mathrm{~mm}$ ) (Lund-Hansen et al. 1999) in such a way that approximately $13-\mathrm{cm}$-high water column was left on top of the 15-cm-high undisturbed sediment core. During the short transportation to the laboratory (less than $15 \mathrm{~min}$ ), the samples were kept cold and dark in a cool box with ice packs (approx. less than $\pm 2{ }^{\circ} \mathrm{C}$ deviation to in situ temperature).

For each station, critical shear stress $\left(\tau_{\text {crit }}\right)$ was determined (at in situ temperature $4.0-5.0{ }^{\circ} \mathrm{C}$ in May; $5.4-20.5{ }^{\circ} \mathrm{C}$ in August) from four replicated cores that were collected $14 \mathrm{~h}$ prior to the determinations (on 2 May and 3 Aug in 2014). Before the critical shear stress measurements, the height of the water in the experimental column was adjusted to $10 \mathrm{~cm}$. For this volume, the hydrodynamics of the chamber is known. The critical shear stress measurements are based on the known current velocities induced by the rotation of the four bladed impeller and the light beam attenuation due to resuspended particles in the experimental chamber with the sediment. A software (PC) is used for controlling the rotation velocity of the impeller and for recording the light beam $(633 \mathrm{~nm})$ attenuation data (see more in detail Lund-Hansen et al. 1999). Critical current velocities at $100 \mathrm{~cm}$ from the bottom $\left(U_{100}\right)$ were calculated by the equation (e.g., Lund-Hansen et al. 1997):

$\tau_{\text {crit }}=C_{\mathrm{d}} \times \rho_{\mathrm{w}} \times U_{100}^{2}\left(\mathrm{~N} \mathrm{~m}^{-2}\right)$,

where

$C_{\mathrm{d}} \quad$ Drag coefficient $(0.003$, muddy sand $)$

$\rho_{\mathrm{w}} \quad$ Water density $\left(\mathrm{kg} \mathrm{m}^{-3}\right)$

$U_{100}$ Current velocity $\left(\mathrm{m} \mathrm{s}^{-1}\right) 1 \mathrm{~m}$ above the bottom

\section{Sediment Core Incubations and Nutrient Flux Determinations}

Each station was sampled on a separate date in spring (5-8 May) and summer (4-7 Aug) in 2014. Seven sediment cores were collected from each station for the nutrient experiments as described above. Three of the samples were used as control columns (C-columns) and in four of the samples resuspension (R-columns) was induced with the strength of $2 \times \tau_{\text {crit }}$ termed $\mathrm{U}^{\prime}$. This is the current speed at $1 \mathrm{~m}$ above the sediment equal to a 2 times higher critical shear stress. The sampling and treatment for the columns were conducted in a dark temperature controlled room as follows:

C-columns were incubated over the period of resuspension treatments, $2-3 \mathrm{~h}$, at in situ temperature:

- Water samples were taken at the beginning and at the end of the incubation

- If a significant concentration change occurred (paired $t$ test), the flux was calculated as mmol m${ }^{-2}$ day $^{-1}$ (Eq. 2) (termed hereafter as the control flux, consists of diffusion, possible gas ebullition, and benthic fauna activity)

R-columns were treated with $2 \times \tau_{\text {crit }}$ for $10 \mathrm{~min}$, at in situ temperature:

Fig. 1 Map of the study area. Stations 1-4, Tvärminne Zoological Station marked with closed black circle (contains data from the National Land Survey of Finland Topographic Database 01/2017)

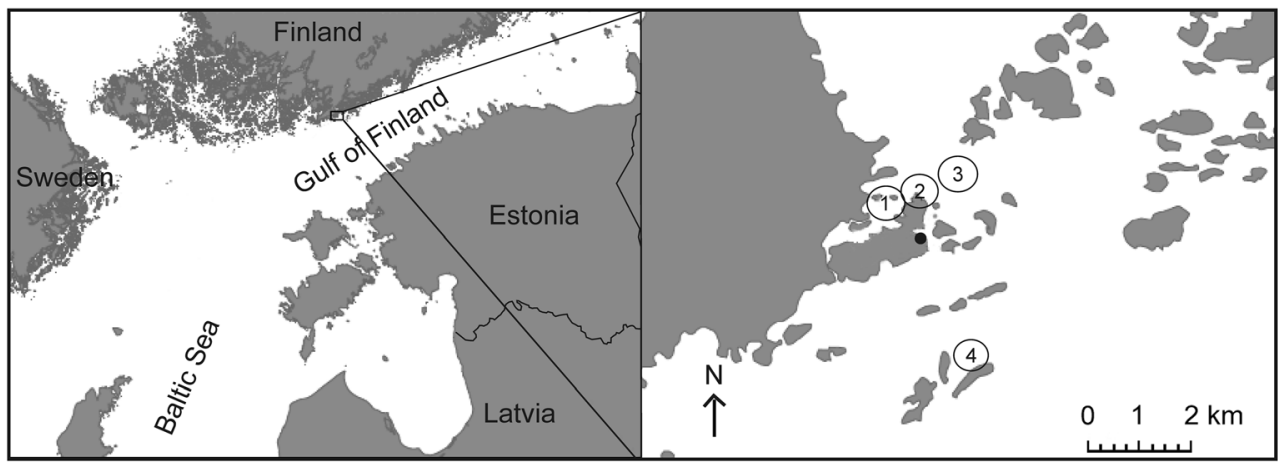


Table 1 Mean ( \pm standard deviation, SD) critical shear stresses $\left(\tau_{\text {crit }}\right)$, critical current velocities at $1 \mathrm{~m}$ above the bottom $\left(\mathrm{U}_{100}\right)$ and current velocities used in the resuspension experiments $\left(\mathrm{U}^{\prime}\right.$, corresponds to $2 \times$ $\tau_{\text {crit }}$ (top panel). Grain size distribution of mineral particles of surface (top-most $1 \mathrm{~cm}$ ) sediment (bottom panel)

\begin{tabular}{|c|c|c|c|c|c|c|c|}
\hline \multirow[t]{2}{*}{ Station } & \multirow[t]{2}{*}{ Depth (m) } & \multicolumn{3}{|l|}{ May } & \multicolumn{3}{|l|}{ August } \\
\hline & & $\tau_{\text {crit }}\left(\mathrm{N} \mathrm{m}^{-2}\right) \pm \mathrm{SD}$ & $U_{100}\left(\mathrm{~cm} \mathrm{~s}^{-1}\right) \pm \mathrm{SD}$ & $\mathrm{U}^{\prime}\left(\mathrm{cm} \mathrm{s}^{-1}\right) \pm \mathrm{SD}$ & $\tau_{\text {crit }}\left(\mathrm{N} \mathrm{m}^{-2}\right) \pm \mathrm{SD}$ & $U_{100}\left(\mathrm{~cm} \mathrm{~s}^{-1}\right) \pm \mathrm{SD}$ & $\mathrm{U}^{\prime}\left(\mathrm{cm} \mathrm{s}^{-1}\right) \pm \mathrm{SD}$ \\
\hline 1 & 6 & $0.040 \pm 0.005$ & $11.5 \pm 0.2$ & $16.3 \pm 0.3$ & $0.021 \pm 0.002$ & $8.4 \pm 0.1$ & $11.8 \pm 0.2$ \\
\hline 2 & 20 & $0.019 \pm 0.002$ & $7.9 \pm 0.5$ & $11.2 \pm 0.7$ & $0.018 \pm 0.002$ & $7.8 \pm 0.5$ & $11.0 \pm 0.7$ \\
\hline 3 & 34 & $0.017 \pm 0.001$ & $7.6 \pm 0.2$ & $10.7 \pm 0.3$ & $0.016 \pm 0.001$ & $7.3 \pm 0.1$ & $10.4 \pm 0.2$ \\
\hline \multirow[t]{3}{*}{4} & 14 & $0.019 \pm 0.001$ & $7.9 \pm 0.2$ & $11.1 \pm 0.3$ & $0.031 \pm 0.008$ & $10.1 \pm 0.1$ & $14.3 \pm 2.0$ \\
\hline & & \multicolumn{3}{|c|}{ Grain size distribution (\%) } & \multicolumn{3}{|c|}{ Grain size distribution $(\%)$} \\
\hline & & $<2 \mu \mathrm{m}$ & $2-63 \mu \mathrm{m}$ & $63-200 \mu \mathrm{m}$ & $<2 \mu \mathrm{m}$ & $2-63 \mu \mathrm{m}$ & $63-200 \mu \mathrm{m}$ \\
\hline 1 & 6 & 3 & 64 & 33 & 2 & 65 & 33 \\
\hline 2 & 20 & 16 & 71 & 13 & 3 & 79 & 18 \\
\hline 3 & 34 & 33 & 65 & 2 & 36 & 63 & 1 \\
\hline 4 & 14 & 17 & 72 & 11 & 25 & 68 & 7 \\
\hline
\end{tabular}

- Total incubation time for R-columns was $20 \mathrm{~min}$ (10 min treatment +10 -min slow stirring), water samples were taken before the treatment and after the 10-min slow stirring phase (used to enable redox reactions to occur and to standardize water sampling conducted with a slow siphon). R-columns underwent the resuspension within the LABEREX chamber in a series (resuspension of all cores was completed within 1-2.5 h)

- If a significant concentration change occurred (paired $t$ test), the flux was calculated ( $m m o l \mathrm{~m}^{-2}$ day $^{-1}$ ) (Eq. 2) and compared with the statistically significant control flux (if observed in C-columns) to separate that from the resuspension-induced flux.

In order to avoid any gradients to establish, a slowly (45 rot./min) stirring magnetic bar was placed in the water column of the incubated C-columns and Rcolumns that were waiting for the treatment. Dissolved oxygen (DO) was measured with optical sensor (YSI6600 V2 sonde, YSI Inc., Yellow Springs, OH, USA YSI) to determine whether laboratory conditions were comparable to the conditions in the near-bottom water in situ. The experimental columns were closed from the top, but not air-tightly to mimic the presence and mixing of oxygenated near-bottom waters during the experiments. The water turbidity was measured (optical sensor, YSI6600 V2 sonde) to determine the level of the resuspension treatment. The DO concentration and turbidity were measured $5 \mathrm{~cm}$ above the sediment. The water samples for the nutrient determinations were collected from the same depth and into acid-rinsed bottles with a siphon (small diameter tube was used as a siphon to avoid creating suction close to sediment surface).

Nutrient fluxes $(F)\left(\right.$ mmol $\mathrm{m}^{-2}$ day $\left.^{-1}\right)$ were calculated as follows:
$F=\frac{\left(C_{\mathrm{b}}-C_{\mathrm{a}}\right)}{t A} \times V$

where

$C_{\mathrm{a}} \quad$ Nutrient concentration in the beginning of the incubation/before the R-treatment $\left(\mathrm{mmol} \mathrm{m}^{-3}\right)$

$C_{\mathrm{b}} \quad$ Nutrient concentration in the end of incubation/after the resuspension treatment $\left(\mathrm{mmol} \mathrm{m}^{-3}\right)$

$V \quad$ Water volume in the experiment column $\left(\mathrm{m}^{3}\right)$

$t$ time (day)

A Area of the treated sediment $\left(\mathrm{m}^{2}\right)$

\section{Diffusive Fluxes Based on the Concentration Gradient at the Sediment-Water Interface}

The diffusive fluxes of nutrients $(J)$ at the sediment-water interface (termed hereafter as the SWI-diffusive fluxes) were calculated according to Fick's first law of diffusion (steady state conditions assumed) as follows (Berner 1980):

$J=\Phi \times D_{\text {sed }} \times \frac{\mathrm{dc}}{\mathrm{dx}}$,

where

$\Phi \quad$ Sediment porosity

$D_{\text {sed }}$ Sediment diffusion coefficient for each nutrient $\left(\mathrm{cm}^{2}\right.$ $\mathrm{s}^{-1}$ )

dc The concentration difference at the sediment-water interface $\left(\mathrm{mol} \mathrm{m}^{-2}\right)$; between the pore water of the surface sediment (at $0-1 \mathrm{~cm}$ depth) and water above the sediment surface (at $5 \mathrm{~cm}$ )

$\mathrm{dx} \quad$ The diffusion distance (m): $0.005 \mathrm{~m}$

Sediment porosity $\Phi$ was estimated from total sediment mass $\left(\mathrm{W}_{\mathrm{t}}\right)$ and sediment dry mass $\left(\mathrm{W}_{\mathrm{s}}\right)$ according 
to Sarazin et al. (1995):

$\Phi=\left\ulcorner 1+\frac{\mathrm{W}_{\mathrm{s}}}{2.5\left(\mathrm{~W}_{\mathrm{t}}-\mathrm{W}_{\mathrm{s}}\right)}\right\rceil^{-1}$

and $D_{\text {sed }}$ according to Clavero et al. (1992):

$D_{\text {sed }}=\frac{D_{\mathrm{i}} \times \Phi^{3}}{1.28}$

$D_{\mathrm{i}}$ is the temperature corrected molar diffusion coefficient $\left(\mathrm{cm}^{2} \mathrm{~s}^{-1}\right)$ of the studied solute (DSi: Schulz 2006; DON, DOP and DOC: Burdige et al. 1992; Boudreau 1996; DIP and $\mathrm{NO}_{x}$ : $\mathrm{Li}$ and Gregory 1974; $\mathrm{NH}_{4}{ }^{+}$: Krom and Berner 1980).

\section{Nutrient Determinations of Water Samples}

The following nutrient concentrations were determined from the water samples: total dissolved phosphorus (TDP) and nitrogen (TDN), dissolved inorganic phosphorus (DIP) and nitrogen forms (DIN: ammonium $\mathrm{NH}_{4}^{+}$, nitrate+nitrite $\mathrm{NO}_{x}$ ), dissolved organic phosphorus (DOP) and nitrogen (DON), dissolved organic carbon (DOC) and dissolved silicate (DSi).

All water samples were filtered immediately after the sampling with $0.2-\mu \mathrm{m}$ membrane filters (prewashed syringe filter, polyethersulfone, VWR International, USA). The concentrations of DIP, $\mathrm{NO}_{x}$, DSi (Thermo Scientific Aquakem 250) (Koroleff 1983) and $\mathrm{NH}_{4}{ }^{+}$(manual indophenol-blue method) (Solórzano 1969) were determined spectrofotometrically from duplicate samples. The method of Solórzano and Sharp (1980) was used before spectrophotometric determination of TDP concentrations. The concentration of DOC was determined from acidified ( $80 \mu \mathrm{l}$ of $2 \mathrm{~mol}^{-1}$ hydrochloric acid into $20 \mathrm{ml}$ of filtrate) duplicate samples with a total organic carbon analyzer (TOC- $\mathrm{V}_{\mathrm{CPH}}$, Shimadzu). The inorganic carbon was purged following the catalytic combustion $\left(720^{\circ} \mathrm{C}\right)$ of organic carbon, which was measured by infrared detection. The concentration of DOP was obtained by subtracting DIP from TDP and the concentration of DON by subtracting DIN from TDN.

\section{Surface Sediment Characteristics, Pore Water and Bottom Fauna Sampling and Analyses, and Current Velocity Measurements}

The pore water samples with three replicates from the surface sediment $(0-1 \mathrm{~cm})$ were collected with Rhizon filters (Rhizon CSS, $0.2-\mu \mathrm{m}$ pore size, polyethersulfon membrane, $5-\mathrm{cm}$ porous, glass fiber strengthener, Rhizosphere Research Products, Netherlands) (Seeberg-Elverfeldt et al. 2005) into 9-ml vacuum tubes at each station (on 28 April and 29 July in 2014). The nutrient concentrations of the diluted samples (1:10) were determined immediately after sampling as described above. Additionally, the concentration of dissolved iron (DFe) was determined from diluted (1:10) and fixed (nitric acid, $0.15 \mathrm{ml}$ 
$\mathrm{HNO}_{3} 65-69 \%$, to $30 \mathrm{ml}$ of sample) samples with the inductively coupled plasma optical emission spectrometry (ICPOES, Thermo Scientific iCAP 6000) (precision and accuracy $<5 \%$ as determined by in-house and reference standards).

Duplicate surface sediment samples (top-most $0.5 \mathrm{~cm}$ ) were collected on the dates of pore water sampling and analyzed for water content (\%) by drying at $105^{\circ} \mathrm{C}$ overnight and for organic content (dried samples) by loss on ignition (LOI) at $550{ }^{\circ} \mathrm{C}$ for $2 \mathrm{~h}$. Total organic nitrogen $\left(\mathrm{N}_{\text {org }}\right)$ and carbon $\left(\mathrm{C}_{\text {org }}\right)$ content of dried samples was determined with CHNSanalyzer (Leco TruSpec Micro, US) (inorganic nitrogen and carbon content assumed negligible, Jilbert et al. 2017). Grain size distribution of surface sediment mineral particles was analyzed with Malvern Mastersizer 2000 laser diffractometer. Pretreated samples (organic material removed with $\mathrm{H}_{2} \mathrm{O}_{2}$, freeze-dried) were soaked in $0.0134 \mathrm{M}$ sodium pyrophosphate $\left(\mathrm{Na}_{4} \mathrm{P}_{2} \mathrm{O}_{7}\right)$ prior to measurements and treated with the diffractometer's ultrasound probe for $30 \mathrm{~s}$ to avoid flocculation of grains. Measurement settings were as follows: general purpose calculation model, measurement time $30 \mathrm{~s}$, background time 15 s., pump speed 2100 revolutions per minute (rpm), and stirrer speed $550 \mathrm{rpm}$. The mean values of three measurements per sample were used for further analyses.

Bottom fauna in the experimental cores was determined after the nutrient experiments. Fauna was sieved (mesh size $0.5 \mathrm{~mm}$ ) and preserved in ethanol and after determination to genus level the number of individuals were calculated.

A recording current meter (Seaguard RCM, Aanderaa Data Instruments, Norway, ADI) with a conductivity sensor was deployed to station 2 at $1 \mathrm{~m}$ above bottom over the period of June 2014-June 2015 to record the near-bottom currents (0.5 h interval) in the Storfjärden basin (covers stations 1-3). For station 4, the current meter was available and deployed only for a short period, late June-mid-August in 2015, i.e., during the following year after the experiments.

\section{Statistical Analyses}

The spatial and temporal differences in critical shear stresses, concentrations of pore water nutrients (top-most $1 \mathrm{~cm}$ ), water, and organic content of the surface sediment, and diffusive nutrient fluxes based on the concentration difference of pore water and near-bottom water were tested using analysis of variance (ANOVA) (SAS Institute Inc. 2008). Paired comparisons were conducted using $t$ test with Bonferroni correction.

The differences in the concentration of the studied solutes, dissolved oxygen, and turbidity between the beginning and end of the incubation (C-columns) or before and after the resuspension treatment ( $\mathrm{R}$-columns) were tested using paired $t$ test. When, based on the paired $t$ test, the difference in the nutrient concentration was significant in both $\mathrm{C}$ - and $\mathrm{R}$ columns for a certain solute, the C-flux and R-flux were calculated and their difference tested using Student's two-sample $t$ test. The spatial and temporal difference of the significant $\mathrm{C}$ and R-fluxes was tested using ANOVA. The normality of datasets $(\ln x+1$ transformed for the nutrient concentrations and turbidity data) measured from experimental columns was verified with Shapiro-Wilk test.

\section{Results}

\section{Critical Shear Stresses and Current Velocities}

The highest critical shear stresses $\left(\tau_{\text {crit }}\right)$ were measured at station $1\left(0.040 \mathrm{~N} \mathrm{~m}^{-2}\right)$ in May and station $4\left(0.031 \mathrm{~N} \mathrm{~m}^{-2}\right)$ in August $\left(t_{24}=3.51, p<0.05\right)$ (Table 1$)$. A viscid biofilm at station 1 in May and coarse organic material at station 4 in August (visual observations) seemed to be reasons for the high $\tau_{\text {crit. }}$ For the other stations, the critical shear stresses showed values from 0.017 to $0.019 \mathrm{~N} \mathrm{~m}^{-2}$ in May and from 0.016 to $0.021 \mathrm{~N} \mathrm{~m}^{-2}$ in August. The highest critical current velocities (1 $\mathrm{m}$ above the bottom) corresponding to the critical shear stresses for the stations 1 in May and 4 in August were $11.5 \mathrm{~cm} \mathrm{~s}^{-1}$ and $10.1 \mathrm{~cm} \mathrm{~s}^{-1}$, respectively. For the other stations, the values ranged from 7.6 to $7.9 \mathrm{~cm} \mathrm{~s}^{-1}$ in May and from 7.3 to $8.4 \mathrm{~cm} \mathrm{~s}^{-1}$ in August (Table 1). The current velocities used for inducing resuspension in the experiments varied between 10.7 and $16.3 \mathrm{~cm} \mathrm{~s}^{-1}$ in May and between 10.4 and $14.3 \mathrm{~cm} \mathrm{~s}^{-1}$ in August (Table 1).

\section{Frequency of Resuspension in the Study Area}

In summer 2014, the wind conditions were quiescent and the critical shear velocity $\left(U_{100}\right)$ at station 2 was not exceeded. In autumn 2014 and following winter, however, both the critical current velocity and the $2 \times \tau_{\text {crit }}$ current velocity (U') were exceeded several times. Additionally, the critical current velocity (determined in spring 2014) was exceeded few times in spring 2015 and the highest observed current velocity was close to the velocity used in the experiments (Fig. 2a, Table 1). It has been shown that large water mass changes in the Storfjärden area can affect all depths studied here (Niemistö et al. 2018) and thus the current velocity measurements conducted at station 2 are representative for the other stations as well. During summer and early autumn in 2014, salinity showed a pattern similar to the current velocity peaking after highest velocity records (Fig. 2a), which suggested that the highest records were due to upwelling events. Such pattern was not as clear in late autumn and winter during the absence of the thermal stratification and more mixed water column.

For station 4, the recording current meter was available and deployed only for the summer 2015, and $U_{100}$ was exceeded once. The current velocity peak was seen as a small increase in 
Fig. 2 Current velocity $\left(\mathrm{cm} \mathrm{s}^{-1}\right)$, the critical current velocity $(\mathrm{cm}$ $\left.\mathrm{s}^{-1}\right)$ at $1 \mathrm{~m}$ above the bottom $\left(U_{100}\right)$ in May and August, $2 \times$ $\tau_{\text {crit }}$ current velocity $\left(\mathrm{U}^{\prime}\right)\left(\mathrm{cm} \mathrm{s}^{-1}\right)$ in May and August, and salinity (psu) for (a) station 2 and (b) station 4
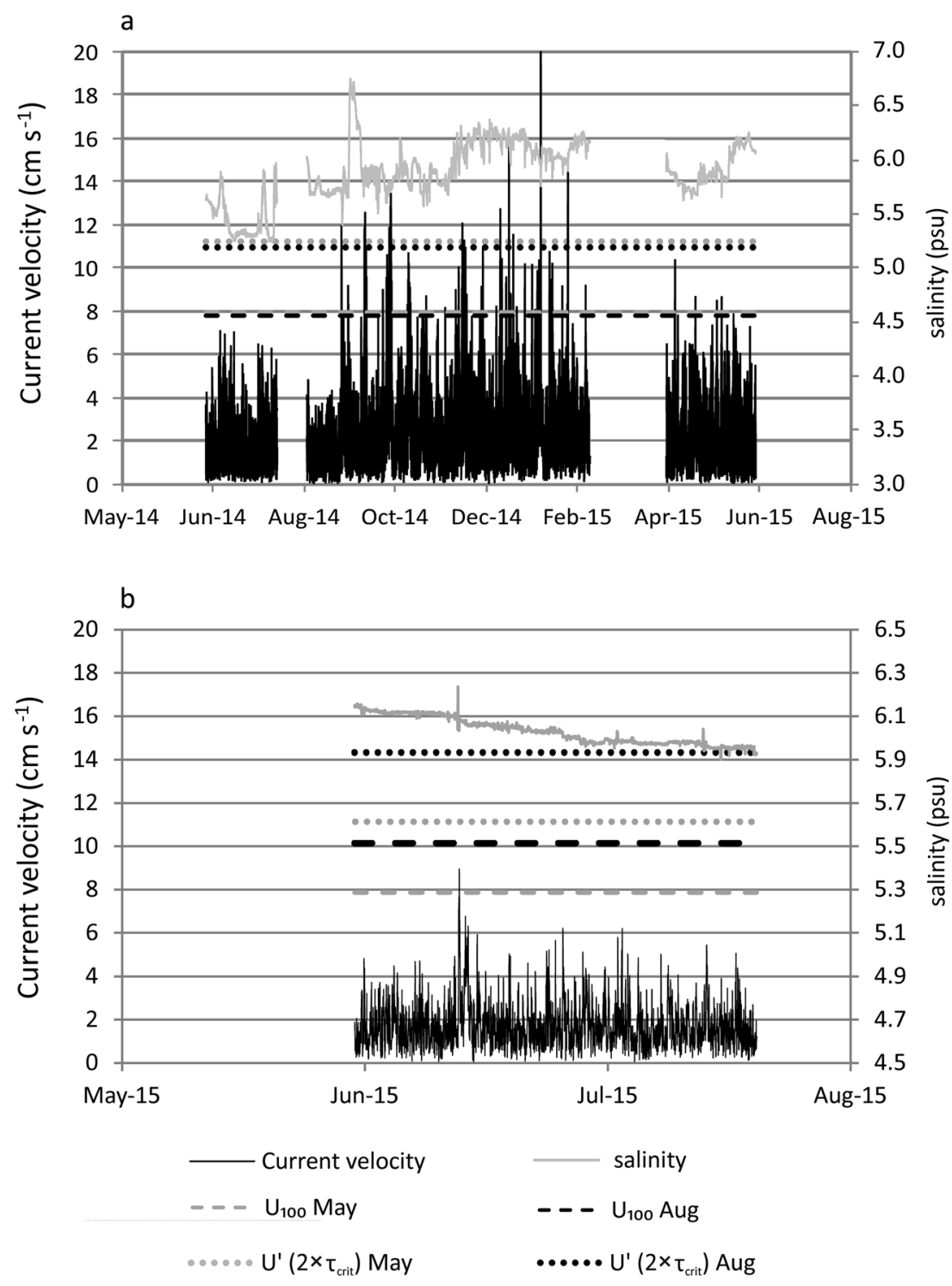

salinity, and therefore attributed to a minor intrusion of deeper waters (Fig. 2b).

\section{Sediment Characteristics, In situ Temperature, and Dissolved Oxygen Concentrations}

In each station, most of the mineral particles of the surface sediments were in the size class of silt, $2-63 \mu \mathrm{m}$ (Table 1). The proportion of the finest particles (grain size $<2 \mu \mathrm{m}$ ) increased towards the deeper bottoms (Table 1). The coarsest sediment was found at the shallowest station 1 , however, the largest particles were fine grained and included in the category of fine sand, 63-200 $\mu \mathrm{m}$ (Table 1). The water content of the surface sediment increased towards the deeper bottoms in the Storfjärden Bay varying from $90 \%$ at station 1 to $98 \%$ at station 3 in May (Table 2). The highest water content, 99\%, was measured at station 4 where the organic content as LOI,
$\mathrm{N}_{\text {org }}$, and $\mathrm{C}_{\text {org }}$ was also highest $(22.7 \%, 2.10 \%$, and $10.7 \%$, respectively). At the other stations that showed lower values compared with station 4 , the organic content as LOI, $\mathrm{N}_{\text {org }}$, and $\mathrm{C}_{\text {org }}$ increased with water depths (Table 2). In August, sediment characteristics were similar to those in May. The water and organic content increased along the water depths, with station 4 being the exception and showing the highest values for all parameters (Table 2).

In May at the time of the experimental sediment core withdrawal, temperature in near-bottom water showed only small variations between stations, from 4.0 to $5.0{ }^{\circ} \mathrm{C}$, and the water was well oxidized (range for DO: 352-384 $\mu \mathrm{mol} 1^{-1}$ ) (Table 2). In August, the presence of a thermal stratification of the water column was shown by temperature differences between shallow water stations $\left(17.5-20.5^{\circ} \mathrm{C}\right)$ and deep water station $\left(5.4{ }^{\circ} \mathrm{C}\right)$. Comparable, the dissolved oxygen showed lowest values at the deepest and highest values at the most 
shallow station ranging from 189 to $259 \mu \mathrm{mol} \mathrm{l}^{-1}$ (Table 2). The concentrations were clearly lower in August than in May though near-bottom waters were still well oxygenated.

\section{Turbidity and Oxygen Concentrations in the Experimental Columns}

\section{Turbidity}

Turbidity data showed a consistent pattern at all stations in May with a significant increase in turbidity with resuspension and no turbidity changes in the control columns (Fig. 3). In August, there were also no changes in turbidity in the C-columns at stations 1 and 3 (Fig. 3). The turbidity decrease at station 2 was probably related to a small disturbance of the column when sampled. The turbidity values of the C-columns at station 4 showed an increase, which, however, was very low compared with the values in the R-columns after the treatment. Apart from station 2, resuspension significantly increased turbidity in the R-columns of all other stations (Fig. 3).

\section{Dissolved Oxygen}

In May at the beginning of the incubations, the oxygen concentration was around $350 \mu \mathrm{mol} \mathrm{l}{ }^{-1}$ in the C-columns of each station and remained unchanged until the end of
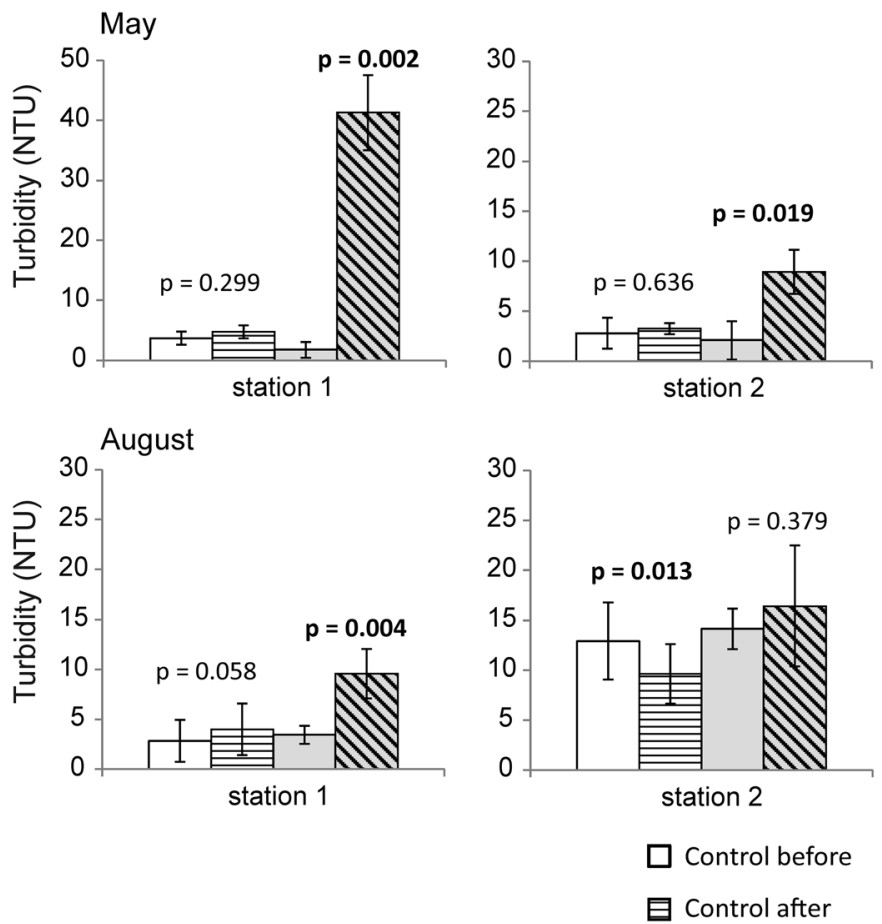

Fig. 3 Mean turbidity values (NTU) ( \pm standard deviation, SD) in the control columns (C) in the beginning and at the end of experiments, and in the resuspension columns (R) before and after the resuspension treatment the experiments (Suppl. 1). In the R-columns, resuspension resulted in statistically significant decreases in the oxygen concentration for every station (Suppl. 1). In August, the oxygen concentrations were lower and the concentration changes less consistent in the $\mathrm{C}$ - and R-columns than in May. However, the conditions remained always oxic (> $190 \mu \mathrm{mol} \mathrm{l}^{-1}$ ) and resembled those recorded in situ (Suppl. 1, Table 2).

\section{Nutrient Fluxes in the Experimental Columns}

In May, statistically significant control fluxes in the Ccolumns were observed only for DIP at station $1(-0.01 \pm$ $0.004)($ mean $\pm \mathrm{SD})$ and for $\mathrm{NO}_{x}$ at station $4(0.36 \pm 0.25 \mathrm{mmol}$ $\mathrm{m}^{-2}$ day $^{-1}$ ) (Table 3 ). In August, also very few statistically significant control fluxes were measured: at station 2 for $\mathrm{NO}_{x} 0.38 \pm 0.18 \mathrm{mmol} \mathrm{m}^{-2}$ day ${ }^{-1}$; at station 4 for $\mathrm{NH}_{4}^{+}$ $6.28 \pm 1.40 \mathrm{mmol} \mathrm{m}^{-2}$ day $^{-1}, \mathrm{NO}_{x} 0.23 \pm 0.06 \mathrm{mmol} \mathrm{m}^{-2}$ day $^{-1}$, and DOC $60.8 \pm 23.1 \mathrm{mmol} \mathrm{m}^{-2}$ day $^{-1}$ (Table 3).

Resuspension resulted in detectable benthic effluxes of the studied solutes approximately in half of the cases in May and August when all nutrients and stations were considered (Table 3). Mainly, the effluxes were observed for $\mathrm{NH}_{4}{ }^{+}$, $\mathrm{NO}_{x}$, and DSi (Table 3). The highest resuspension-induced $\mathrm{NH}_{4}{ }^{+}$efflux was measured at station 4 in August, $74.5 \pm$ $17.6 \mathrm{mmol} \mathrm{m}^{-2}$ day $^{-1}$, while for the other stations, the effect was markedly lower $\left(t_{12}=3.15, p<0.05\right)$ (Table 3$)$. The highest $\mathrm{NO}_{x}$ fluxes were measured for the stations $3(2.89 \pm$
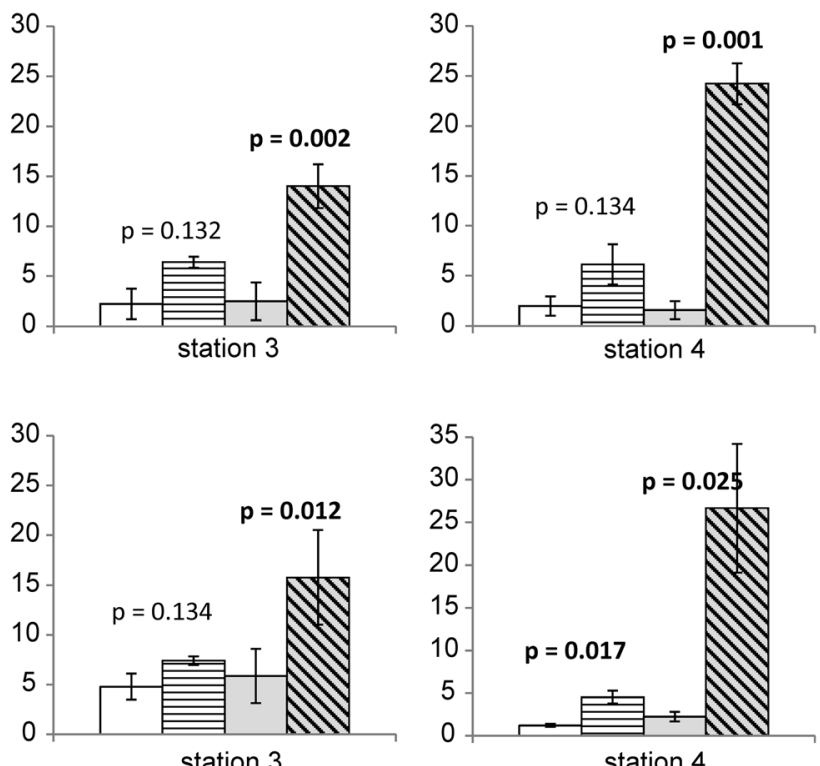

Resupension before

$\mathbf{Q}$ Resuspension after

for different stations. The $p$ values of paired $t$ test presented on top of the turbidity bars, $\mathrm{df}=2$ for $\mathrm{C}$-columns and $\mathrm{df}=3$ for R-columns. Significant differences $(p<0.05)$ denoted with bold $p$ values 
Table 3 Control (C-columns) and resuspension-induced (R-columns) benthic nutrient fluxes $\left(\mathrm{mmol} \mathrm{m}^{-2} \mathrm{day}^{-1}\right)$ measured from the experimental columns at different stations. Fluxes are marked with italic font, when statistically significant fluxes in both, the $\mathrm{C}$ - and R-columns, were detected for a certain solute (paired $t$ test: $\mathrm{df}=2$ for $\mathrm{C}$-columns and $\mathrm{df}=3$ for Rcolumns, flux value given, if $p<0.05$ )

\begin{tabular}{|c|c|c|c|c|c|c|c|}
\hline & Station & $\mathrm{NH}_{4}^{+}$ & $\mathrm{NO}_{x}$ & DIP & $\mathrm{DSi}$ & DOP & DOC \\
\hline \multicolumn{8}{|c|}{ Mean flux $( \pm \mathrm{SD})$ in C-columns $\left(\mathrm{mmol} \mathrm{m}^{-2}\right.$ day $\left.^{-1}\right)$} \\
\hline \multirow[t]{4}{*}{ May } & 1 & $*$ & $*$ & $0.01 \pm 0.04$ & $*$ & $*$ & NA \\
\hline & 2 & $*$ & $*$ & $*$ & $*$ & $*$ & NA \\
\hline & 3 & $*$ & $*$ & $*$ & $*$ & $*$ & NA \\
\hline & 4 & $*$ & $0.36 \pm 0.25$ & $*$ & $*$ & $*$ & NA \\
\hline \multirow[t]{4}{*}{ August } & 1 & $*$ & $*$ & $*$ & $*$ & $*$ & $*$ \\
\hline & 2 & $*$ & $0.38 \pm 0.18$ & $*$ & $*$ & $*$ & $*$ \\
\hline & 3 & $*$ & $*$ & $*$ & $*$ & $*$ & $*$ \\
\hline & 4 & $6.28 \pm 1.40$ & $0.23 \pm 0.06$ & $*$ & $*$ & $*$ & $60.8 \pm 23.1$ \\
\hline \multicolumn{8}{|c|}{ Mean flux $( \pm \mathrm{SD})$ in R-columns $\left(\mathrm{mmol} \mathrm{m}^{-2}\right.$ day $\left.^{-1}\right)$} \\
\hline \multirow[t]{4}{*}{ May } & 1 & $*$ & $*$ & $*$ & $*$ & $*$ & NA \\
\hline & 2 & $*$ & $*$ & $*$ & $14.3 \pm 5.69$ & $0.35 \pm 0.16$ & NA \\
\hline & 3 & $*$ & $2.89 \pm 0.57$ & $0.95 \pm 0.48$ & $32.1 \pm 15.5$ & $*$ & NA \\
\hline & 4 & $1.93 \pm 1.00$ & $5.30 \pm 3.17$ & $0.76 \pm 0.49$ & $35.1 \pm 12.7$ & $0.20 \pm 0.09$ & NA \\
\hline \multirow[t]{4}{*}{ August } & 1 & $5.22 \pm 2.85$ & $1.30 \pm 0.58$ & $*$ & $19.4 \pm 7.67$ & $0.70 \pm 0.41$ & $*$ \\
\hline & 2 & $8.18 \pm 3.18$ & $1.76 \pm 0.27$ & $*$ & $*$ & $*$ & $553 \pm 270$ \\
\hline & 3 & $*$ & $*$ & $*$ & $*$ & $*$ & $*$ \\
\hline & 4 & $74.5 \pm 17.6$ & $1.49 \pm 0.15$ & $*$ & $99.3 \pm 13.9$ & $*$ & $683 \pm 300$ \\
\hline
\end{tabular}

*flux insignificant, i.e., $p>0.05$

$N A$, no data

$0.57 \mathrm{mmol} \mathrm{m}^{-2}$ day $\left.^{-1}\right)$ and $4\left(5.30 \pm 3.17 \mathrm{mmol} \mathrm{m}^{-2}\right.$ day $\left.^{-1}\right)$ in May $\left(t_{15}=3.29, p<0.05\right)$. In August, resuspension resulted in lower fluxes that ranged from 1.30 to $1.76 \mathrm{mmol} \mathrm{m}^{-2}$ day $^{-1}$ (Table 3). As the $\mathrm{NH}_{4}{ }^{+}$flux, the resuspension-induced DSi flux was highest at station 4 in August, $99.3 \pm 13.9 \mathrm{mmol}$ $\mathrm{m}^{-2}$ day $^{-1}$ (Table 3 ). The effluxes ranged from 14.3 to $35.1 \mathrm{mmol} \mathrm{m}^{-2}$ day $^{-1}$ in May and August at the other stations (Table 3). DIP showed significant effluxes due to resuspension only in May (station 3: $0.95 \pm 0.48 \mathrm{mmol} \mathrm{m}^{-2}$ day $^{-1}$; station 4: $0.76 \pm 0.49 \mathrm{mmol} \mathrm{m}^{-2}$ day $^{-1}$ ), whereas significant DOP effluxes were recorded at stations 2 and 4 in May and at station 1 in August, the range being from 0.20 to $0.70 \mathrm{mmol}$ $\mathrm{m}^{-2}$ day $^{-1}$ (Table 3). Significant resuspension-induced fluxes of DOC were measured only in August at stations 2 (553 \pm $270 \mathrm{mmol} \mathrm{m}^{-2}$ day $\left.^{-1}\right)$ and $4\left(683 \pm 300 \mathrm{mmol} \mathrm{m}^{-2}\right.$ day $\left.^{-1}\right)$ (Table 3). No detectable fluxes of DON were measured for any of the stations in May or August (data not shown).

A comparison of control and resuspension-induced benthic fluxes measured in the experimental columns were conducted. The control flux of $\mathrm{NO}_{x}$ constituted $7 \%$ of the resuspension-induced flux at station 4 in May. In August at the same station, the control fluxes for $\mathrm{NH}_{4}{ }^{+}$, $\mathrm{NO}_{x}$, and DOC constituted $8 \%, 15 \%$, and $9 \%$ of the resuspension-induced fluxed, respectively. At station 2, the control flux of $\mathrm{NO}_{x}$ constituted $22 \%$ of the resuspension-induced flux in August (Table 3).

\section{Diffusive Fluxes Based on the Concentration Gradient in the Sediment-Water Interface}

Most of the solutes showed higher near-bottom concentrations in August than in May at the study stations (Table 4). In spatial comparisons, the near-bottom concentrations of inorganic solutes $\left(\mathrm{NH}_{4}{ }^{+}, \mathrm{NO}_{x}, \mathrm{DIP}\right.$, and DSi) were highest at station 3 in August $\left(t_{24}=2.88, p<0.05\right)$. In May, this was also the case $\left(t_{24}=2.88, p<0.05\right)$, but station 4 showed values of similar level for $\mathrm{NO}_{x}$ and DSi. The organic solutes (DOP, DON) showed no differences between stations in May, whereas the lowest concentrations for DON and DOC were found at station 3 in August $\left(t_{24}=2.88, p<0.05\right)$ (Table 4$)$.

In general, the concentrations of studied solutes in the pore water seemed to be higher at every station before the August experiments compared with May experiments, but due to high deviation among replicates, only few statistically significant differences were detected. Station 1 showed higher concentrations in the end of July for three solutes, $\mathrm{NH}_{4}{ }^{+}$, DIP, and DSi, and station 3 for $\mathrm{NO}_{x}$ (Table 5). In addition to the solutes determined from the near-bottom water, the concentration of DFe was determined for the pore waters and a significant difference between April and July was found only at the station 1 (Table 5). The spatial pairwise comparisons showed that the concentration of DFe was lowest at stations 3 and 4 in April $\left(t_{7}=3.64 p<0.05\right)$ and July $\left(t_{8}=3.48, p<0.05\right)$. The 
Table 4 Initial mean concentrations of the solutes $( \pm \mathrm{SD})(\mu \mathrm{M})$ in the near-bottom water in the experiment cores in the beginning of the experiments in May and August (NA, no data). Statistical results of the Student's two-sample $t$ test for the comparisons between May and August

\begin{tabular}{|c|c|c|c|c|}
\hline Solute $(\mu \mathrm{M})$ & Station 1 & Station 2 & Station 3 & Station 4 \\
\hline \multicolumn{5}{|c|}{ May } \\
\hline $\mathrm{NH}_{4}^{+}$ & $0.30 \pm 0.11$ & $0.50 \pm 0.26$ & $2.44 \pm 1.37$ & $0.73 \pm 0.19$ \\
\hline $\mathrm{NO}_{x}$ & NA & $0.29 \pm 0.10$ & $0.99 \pm 0.20$ & $0.97 \pm 0.37$ \\
\hline DIP & $0.28 \pm 0.03$ & $0.36 \pm 0.02$ & $0.65 \pm 0.10$ & $0.48 \pm 0.05$ \\
\hline $\mathrm{DSi}$ & $6.34 \pm 0.50$ & $9.26 \pm 1.93$ & $13.7 \pm 2.53$ & $13.0 \pm 1.66$ \\
\hline DON & $19.5 \pm 1.04$ & $19.5 \pm 1.27$ & $19.2 \pm 0.94$ & $20.8 \pm 2.20$ \\
\hline DOP & $0.24 \pm 0.02$ & $0.19 \pm 0.02$ & $0.21 \pm 0.11$ & $0.23 \pm 0.03$ \\
\hline DOC & NA & NA & NA & NA \\
\hline \multicolumn{5}{|c|}{ August } \\
\hline $\mathrm{NH}_{4}^{+}$ & $1.75 \pm 0.66$ & $3.27 \pm 0.39$ & $9.26 \pm 1.52$ & $4.36 \pm 0.97$ \\
\hline $\mathrm{NO}_{x}$ & $0.10 \pm 0.03$ & $0.32 \pm 0.11$ & $3.97 \pm 0.88$ & $0.19 \pm 0.08$ \\
\hline DIP & $0.29 \pm 0.05$ & $0.39 \pm 0.02$ & $1.59 \pm 0.29$ & $0.42 \pm 0.06$ \\
\hline $\mathrm{DSi}$ & $13.0 \pm 1.58$ & $14.8 \pm 1.97$ & $30.8 \pm 6.13$ & $17.3 \pm 2.39$ \\
\hline DON & $27.6 \pm 2.31$ & $22.8 \pm 1.52$ & $19.8 \pm 3.86$ & $25.3 \pm 2.68$ \\
\hline DOP & $0.29 \pm 0.03$ & $0.27 \pm 0.02$ & $0.25 \pm 0.08$ & $0.32 \pm 0.05$ \\
\hline DOC & $674 \pm 36$ & $641 \pm 92$ & $362 \pm 70$ & $619 \pm 15$ \\
\hline \multicolumn{5}{|c|}{ Difference May vs August, $t$ test: $t_{\mathrm{df}}, p$ value } \\
\hline $\mathrm{NH}_{4}^{+}$ & $t_{12}=-10.3, p<0.001$ & $t_{12}=-11.6, p<0.001$ & $t_{12}=-7.80, p<0.001$ & $t_{12}=-14.8, p<0.001$ \\
\hline $\mathrm{NO}_{x}$ & NA & $t_{11.2}=-0.59, p=0.568$ & $t_{10.4}=-10.5, p<0.001$ & $t_{11.8}=7.80, p<0.001$ \\
\hline DIP & $t_{10.3}=-0.48, p=0.642$ & $t_{11.3}=-2.49, p=0.029$ & $t_{10.2}=-8.53, p<0.001$ & $t_{9.8}=1.90, p=0.086$ \\
\hline $\mathrm{DSi}$ & $t_{10.5}=-13.6, p<0.001$ & $t_{10.0}=-5.35, p<0.001$ & $t_{10.5}=-7.04, p<0.001$ & $t_{11.7}=-4.14, p=0.001$ \\
\hline DON & $t_{10.1}=-9.36, p<0.001$ & $t_{12}=-4.36, p=0.001$ & $t_{12}=-0.15, p=0.884$ & $t_{12}=-3.56, p=0.004$ \\
\hline DOP & $t_{11.5}=-4.56, p=0.001$ & $t_{10.9}=-8.75, p<0.001$ & $t_{11.9}=-0.99, p=0.341$ & $t_{10.2}=-4.22, p=0.002$ \\
\hline DOC & NA & NA & NA & NA \\
\hline
\end{tabular}

lowest DFe/DIP ratios (1.2 in April, 1.5 in July) were measured for station 4 that differed significantly, apart from station 3 , from the other stations in April $\left(t_{7}=3.64, p<0.05\right)$ and July $\left(t_{8}=3.48, p<0.05\right)$ (Table 5). The DFe/DSi ratios were lowest in the stations 3 and 4 in April $\left(t_{7}=3.64, p<0.05\right)$ and July $\left(t_{8}\right.$ $=3.48, p<0.05)$ but showed no temporal differences for any of the stations (Table 5).

In general, the diffusive fluxes at the sediment-water interface (SWI-diffusive fluxes) based on the concentration gradient between the pore water (top-most $1 \mathrm{~cm}$ ) and nearbottom water showed no differences for the solutes at the different stations between May and August. The only exceptions were $\mathrm{NH}_{4}{ }^{+}\left(t_{4}=4.27, p=0.013\right)$ and DIP $\left(t_{2.2}=\right.$ 4.62, $p=0.036$ ) with higher fluxes in August, and $\mathrm{NO}_{x}$ with a lower flux $\left(t_{2.1}=4.07, p=0.049\right)$ in August at station 1 (Table 6).

On the studied dates, the SWI-diffusive fluxes of $\mathrm{NH}_{4}{ }^{+}$and $\mathrm{NO}_{x}$ ranged from 0.02 to $0.19 \mathrm{mmol} \mathrm{m}^{-2}$ day $^{-1}$ and from 0.01 to $0.03 \mathrm{mmol} \mathrm{m}^{-2}$ day $^{-1}$, respectively. The fluxes of DIP and DSi ranged from 0.03 to $0.27 \mathrm{mmol} \mathrm{m}^{-2}$ day $^{-1}$ and from 0.28 to $0.98 \mathrm{mmol} \mathrm{m}^{-2}$ day $^{-1}$, respectively. Among the organic solutes, DOC showed the highest range varying from -0.24 to
$0.73 \mathrm{mmol} \mathrm{m}^{-2} \mathrm{day}^{-1}$, whereas DON ranged from 0.08 to $0.21 \mathrm{mmol} \mathrm{m}^{-2} \mathrm{day}^{-1}$ and DOP from $<0.01$ to $0.04 \mathrm{mmol} \mathrm{m}^{-2}$ day $^{-1}$ (Table 6).

\section{Discussion}

\section{Frequency of Resuspension Events in the Study Area and Relevance of the Treatment Level of the Experiments}

The LABEREX chamber has been validated in an intercalibration study comprising several chambers for resuspension and sediment flux studies (Tengberg et al. 2005), and applied in several resuspension studies in the Baltic Sea area (Christiansen et al. 2002; LundHansen et al. 2002). A comparison shows that present critical shear stresses in GoF are very similar to those obtained in the studies for comparable water depths and sediment conditions. Although the surface sediments of the stations studied here seemed to be fairly sheltered based on the critical shear stress values measured for spring and summer, these values were exceeded several 
Table 5 Pore water concentrations of $\mathrm{NH}_{4}{ }^{+}, \mathrm{NO}_{x}$, DIP, DSi, DON, DOP, DOC, and DFe of the surface sediment $(0-1 \mathrm{~cm})$ at the studied stations $1 \mathrm{week}$ before the experiments in spring and summer (NA, no data). Statistical results of Student's two-sample $t$ test for the comparisons between studied months

\begin{tabular}{|c|c|c|c|c|}
\hline Solute $(\mu \mathrm{M}) /$ ratio & Station 1 & Station 2 & Station 3 & Station 4 \\
\hline \multicolumn{5}{|c|}{28 April } \\
\hline $\mathrm{NH}_{4}^{+}$ & $15.4 \pm 0.95$ & $38.7 \pm 8.46$ & $28.9 \pm 8.16$ & $37.8 \pm 8.42$ \\
\hline $\mathrm{NO}_{x}$ & $2.54 \pm 1.17$ & $2.60 \pm 0.91$ & $2.86 \pm 1.38$ & $2.55 \pm 0.71$ \\
\hline DIP & $4.66 \pm 1.73$ & $8.47 \pm 5.02$ & $6.96 \pm 5.10$ & $7.28 \pm 1.01$ \\
\hline $\mathrm{DSi}$ & $47.5 \pm 0.16$ & $76.4 \pm 14.1$ & $39.0 \pm 9.41$ & $51.7 \pm 16.1$ \\
\hline $\mathrm{DON}$ & $101 \pm 32.8$ & $91.5 \pm 13.2$ & $109 \pm 11.9$ & $86.7 \pm 16.3$ \\
\hline DOP & $3.22 \pm 3.90$ & $1.97 \pm 0.74$ & $1.00 \pm 0.32$ & $0.93 \pm 0.36$ \\
\hline DOC & NA & $\mathrm{NA}$ & NA & NA \\
\hline $\mathrm{DFe}$ & $94.0 \pm 3.80$ & $98.5 \pm 25.8$ & $16.4 \pm 9.06$ & $9.55 \pm 8.88$ \\
\hline DFe/DIP & $19.5 \pm 6.2$ & $14.9 \pm 9.0$ & $2.7 \pm 0.9$ & $1.2 \pm 1.0$ \\
\hline $\mathrm{DFe} / \mathrm{DSi}$ & $2.0 \pm 0.1$ & $1.3 \pm 0.4$ & $0.4 \pm 0.1$ & $0.2 \pm 0.1$ \\
\hline \multicolumn{5}{|c|}{29 July } \\
\hline $\mathrm{NH}_{4}^{+}$ & $62.6 \pm 19.8$ & $32.4 \pm 10.5$ & $33.2 \pm 2.49$ & $90.5 \pm 64.7$ \\
\hline $\mathrm{NO}_{x}$ & $2.35 \pm 0.67$ & $3.00 \pm 0.35$ & $6.08 \pm 0.15$ & $1.99 \pm 0.22$ \\
\hline DIP & $46.2 \pm 14.3$ & $28.4 \pm 17.6$ & $11.8 \pm 1.13$ & $30.1 \pm 30.7$ \\
\hline $\mathrm{DSi}$ & $123 \pm 24.1$ & $95.0 \pm 39.1$ & $56.8 \pm 6.50$ & $88.3 \pm 40.1$ \\
\hline DON & $107 \pm 35.0$ & $67.6 \pm 2.35$ & $124 \pm 28.2$ & $106 \pm 11.1$ \\
\hline DOP & $9.46 \pm 7.40$ & $11.1 \pm 7.55$ & $2.45 \pm 0.81$ & $0.98 \pm 1.00$ \\
\hline DOC & $1070 \pm 194$ & $490 \pm 187$ & $692 \pm 84.4$ & $985 \pm 432$ \\
\hline $\mathrm{DFe}$ & $193 \pm 34.5$ & $143 \pm 89.5$ & $32.2 \pm 4.74$ & $28.9 \pm 13.7$ \\
\hline $\mathrm{DFe} / \mathrm{DIP}$ & $4.4 \pm 1.2$ & $5.1 \pm 0.1$ & $2.7 \pm 0.3$ & $1.5 \pm 1.0$ \\
\hline $\mathrm{DFe} / \mathrm{DSi}$ & $1.6 \pm 0.2$ & $1.4 \pm 0.5$ & $0.6 \pm 0.1$ & $0.3 \pm 0.1$ \\
\hline \multicolumn{5}{|c|}{ Difference April vs July, $t$ test: $t_{\mathrm{df}}, p$ value } \\
\hline $\mathrm{NH}_{4}^{+}$ & $t_{3}=4.26, p=0.050$ & $t_{4}=0.80, p=0.469$ & $t_{2.4}=0.87, p=0.464$ & $t_{4}=1.40, p=0.234$ \\
\hline $\mathrm{NO}_{x}$ & $t_{3}=0.21, p=0.862$ & $t_{4}=0.71, p=0.536$ & $t_{4}=4.03, p=0.016$ & $t_{2.4}=1.31, p=0.303$ \\
\hline DIP & $t_{3}=4.96, p=0.035$ & $t_{4}=1.88, p=0.183$ & $t_{2.2}=1.60, p=0.240$ & $t_{4}=1.29, p=0.267$ \\
\hline $\mathrm{DSi}$ & $t_{3}=5.43, p=0.032$ & $t_{4}=0.78, p=0.504$ & $t_{3.6}=2.69, p=0.062$ & $t_{2.6}=1.47, p=0.251$ \\
\hline DON & $t_{3}=0.15, p=0.892$ & $t_{2.1}=3.08, p=0.084$ & $t_{2.7}=0.87, p=0.454$ & $t_{3.5}=1.72, p=0.170$ \\
\hline DOP & $t_{3}=0.93, p=0.420$ & $t_{4}=2.08, p=0.106$ & $t_{2.6}=2.89, p=0.074$ & $t_{3}=0.93, p=0.424$ \\
\hline DOC & NA & NA & NA & NA \\
\hline $\mathrm{DFe}$ & $t_{3}=4.94, p=0.036$ & $t_{4}=0.83, p=0.482$ & $t_{3.0}=2.68, p=0.075$ & $t_{3.4}=2.06, p=0.120$ \\
\hline $\mathrm{DFe} / \mathrm{DIP}$ & $t_{3}=4.16, p=0.047$ & $t_{4}=1.91, p=0.129$ & $t_{2.6}=0.13, p=0.905$ & $t_{4}=0.32, p=0.764$ \\
\hline $\mathrm{DFe} / \mathrm{DSi}$ & $t_{3}=3.02, p=0.057$ & $t_{3.7}=0.19, p=0.856$ & $t_{3.3}=1.97, p=0.136$ & $t_{3.7}=1.60, p=0.192$ \\
\hline
\end{tabular}

times in the Storfjärden. The $2 \times \tau_{\text {crit }}$ current velocities $\left(\mathrm{U}^{\prime}\right)$ applied for resuspension in the experiments were mainly exceeded in autumn and winter, but also in spring. The studied summers of 2014 and 2015 were both quiescent, and the $2 \times \tau_{\text {crit }}$ current velocities used in the experiments in August were not exceeded. However, current velocities of similar magnitudes and fast exchanges of large water masses due to upwelling events have been observed in the study area (Haapala 1994; Niemistö et al. 2018). Therefore, it is assumed that the nutrient fluxes reported here represent the potential level of internal nutrient loading in case of a resuspension event.

\section{Turbidity and Oxygen Concentrations in the Experimental Columns}

The turbidity values measured in May revealed no changes in the C-columns but significant increases in the R-columns for every station, indicating undisturbed sediment core withdrawal and successful resuspension treatment. In August, the development of turbidity values was almost as consistent, however, with few exceptions. The increase in turbidity in the $\mathrm{C}$ columns of the most organic station 4 seemed to be due to gas bubbling (visual observation) resulting from organic material degradation and pressure change after sediment core withdrawal. The turbidity decrease in the C-columns and non- 
Table 6 Diffusive fluxes $\left(\mathrm{mmol} \mathrm{m}^{-2} \mathrm{day}^{-1}\right)$ of each solute based on the concentration gradient between the pore water of the surface sediment $(0-1 \mathrm{~cm})$ and near-bottom water (termed as the SWI-diffusive fluxes)

\begin{tabular}{cllllllll}
\hline \multicolumn{7}{c}{ Mean flux $( \pm \mathrm{SD})\left(\mathrm{mmol} \mathrm{m}^{-2} \mathrm{day}^{-1}\right)$} \\
\cline { 2 - 8 } & Station & $\mathrm{NH}_{4}{ }^{+}$ & $\mathrm{NO}_{x}$ & $\mathrm{DIP}$ & $\mathrm{DSi}$ & $\mathrm{DON}$ & DOP & DOC \\
\hline 28 April & 1 & $0.02 \pm 0.004$ & $0.03 \pm 0.01$ & $0.03 \pm 0.03$ & $0.42 \pm 0.29$ & $0.16 \pm 0.06$ & $0.01 \pm 0.02$ & $\mathrm{NA}$ \\
& 2 & $0.05 \pm 0.01$ & $0.03 \pm 0.01$ & $0.08 \pm 0.05$ & $0.98 \pm 0.21$ & $0.21 \pm 0.14$ & $0.01 \pm 0.003$ & $\mathrm{NA}$ \\
& 3 & $0.03 \pm 0.01$ & $0.02 \pm 0.01$ & $0.06 \pm 0.05$ & $0.38 \pm 0.14$ & $0.18 \pm 0.02$ & $<0.01$ & $\mathrm{NA}$ \\
& 4 & $0.05 \pm 0.01$ & $0.02 \pm 0.01$ & $0.07 \pm 0.01$ & $0.54 \pm 0.32$ & $0.14 \pm 0.03$ & $<0.01$ & $\mathrm{NA}$ \\
& 4 & $0.09 \pm 0.03$ & $0.01 \pm 0.002$ & $0.27 \pm 0.09$ & $0.82 \pm 0.18$ & $0.11 \pm 0.05$ & $0.03 \pm 0.02$ & $0.53 \pm 0.26$ \\
& 1 & $0.06 \pm 0.02$ & $0.01 \pm 0.002$ & $0.24 \pm 0.15$ & $0.84 \pm 0.41$ & $0.08 \pm 0.004$ & $0.04 \pm 0.03$ & $-0.24 \pm 0.35$ \\
& 2 & $0.05 \pm 0.01$ & $0.01 \pm 0.001$ & $0.09 \pm 0.01$ & $0.28 \pm 0.07$ & $0.20 \pm 0.05$ & $0.01 \pm 0.004$ & $0.03 \pm 0.16$ \\
& 3 & $0.19 \pm 0.14$ & $0.01 \pm 0.001$ & $0.27 \pm 0.27$ & $0.79 \pm 0.45$ & $0.16 \pm 0.02$ & $<0.01$ & $0.73 \pm 0.86$ \\
\hline
\end{tabular}

significant effect of the resuspension at station 2 could, however, be related to a slight disturbance during sediment sampling or high pre-incubation turbidity due to bioturbation at the time of sample withdrawal (Davis 1993). Indicative of this, the raised turbidity values were recorded in all C- and $\mathrm{R}$-columns from this station prior to the experiments.

The presence or absence of dissolved oxygen is fundamental for the occurrence of some redox-sensitive soluble nutrients such as DIP, DSi, and DOC (e.g., Gunnars and Blomqvist 1997; Sigg and Stumm 1981; Anderson and Benjamin 1985; Skoog and Arias-Esquivel 2009), and also for biological processing of different nitrogen forms via nitrification and denitrification (Thamdrup and Dalsgaard 2008). As the experimental set-up was not air tight, the aim of the present study was not to calculate exact benthic oxygen fluxes but retain the conditions similar to in situ conditions. The slow mixing of water in the experimental columns with magnetic bars and slight exchange of air through the top of the columns expectedly retained the oxygen concentration at the preexperimental level in the C-columns of every station during the May experiments. Although the conditions were not as consistent in August, the changes were minor and oxygen concentrations similar to the in situ conditions. Therefore, it can be concluded that experimental set-up was relevant to study redox-sensitive nutrients in shallow oxic bottoms.

\section{Control, SWI-diffusive, and Resuspension-Induced Nutrient Fluxes}

Due to the short experiment time, very few control fluxes were detected in the incubations. Most of these fluxes were measured in August for station 4 having the most organic rich sediment. This suggests that bacterial degradation of organic material and nutrient regeneration was higher in August at this station compared with the other stations. The conclusion was supported by the fact that the activity of heterotrophic bacteria in the studied area has been observed to be highest during the warm summer months (Vetterli et al. 2015). Additionally, the nutrients that showed significant control fluxes were $\mathrm{NH}_{4}{ }^{+}$, $\mathrm{NO}_{x}$, and DOC indicating organic material degradation and nitrification of ammonium (Ståhl et al. 2004; Thamdrup and Dalsgaard 2008). However, the detected control fluxes (observed in 5 occasions out of 21 significant resuspensioninduced fluxes) constituted only up to $7-22 \%$ of the resuspension-induced fluxes stressing the importance of possible resuspension events for the benthic nutrient entrainment at the study area. It is common that the resuspension-induced benthic fluxes exceed the fluxes of undisturbed sediments (e.g., Reddy et al. 1996). The control fluxes, in turn, were more than one order of magnitude higher than the SWIdiffusive fluxes. Such discrepancies are commonly observed (e.g., Barbanti et al. 1992; Berelson et al. 2015) and considered to be due to lack of physical factors (slow currents, gas ebullition) and bioturbation related processes in the diffusive flux calculations based on concentration gradient in the sediment-water interface (e.g., Barbanti et al. 1992). A slow mixing was induced in the experimental columns to avoid unnaturally stagnant conditions and concentration gradients to be established. Additionally, normal benthic fauna was present in the experimental sediments. These factors could explain the observed discrepancies between the control fluxes and SWI-diffusive fluxes. Because the control incubations were short and very few fluxes were detected, the SWIdiffusive fluxes provided a baseline for the diffusion of benthic nutrients in the studied area and pointed out that diffusion is of minor magnitude in comparison to resuspension-induced nutrient fluxes.

\section{Resuspension-Induced $\mathrm{NH}_{4}^{+}$and $\mathrm{NO}_{x}$ Fluxes}

The highest resuspension-induced $\mathrm{NH}_{4}{ }^{+}$flux was measured in August at station 4 having the highest organic content. This result is in concordance with the earlier findings of AlmrothRosell et al. (2012) who observed the highest instantaneous 
increase in the $\mathrm{NH}_{4}{ }^{+}$concentration due to resuspension of sediment with the highest organic content. Additionally, as mentioned above, the degradation of organic material during the productive season (Vetterli et al. 2015) resulted in high $\mathrm{NH}_{4}{ }^{+}$ pore water concentrations in August, which would also explain the significant $\mathrm{NH}_{4}{ }^{+}$fluxes observed at stations 1 and 2 .

The resuspension-induced $\mathrm{NH}_{4}{ }^{+}$fluxes measured in the present study were from 10- to 20 -fold higher than fluxes recorded during the in situ studies conducted with Göteborg Benthic landers in the same area close to stations 1 and 2 (near-bottom oxygen concentrations comparable to the present study) (Niemistö et al. 2018). In fact, the resuspension-induced decrease of the benthic $\mathrm{NH}_{4}{ }^{+}$flux was observed in the in situ study of Niemistö et al. (2018) with incubation periods of $12 \mathrm{~h}$, which was suggested to be due to enhanced nitrification. We emphasize that only the instantaneous effects of resuspension were studied here, and the treatment levels of these two studies were most likely different. However, the short resuspension treatment by the LABEREX chamber caused a decrease of dissolved oxygen and strong increase of $\mathrm{NH}_{4}{ }^{+}$in near-bottom water indicating that the surface sediment was aerated and rich in substrate for nitrification. Nitrification is a biologically mediated process having rates unlikely to be observed within the timescale of our treatment (e.g., Thamdrup and Dalsgaard 2008; Jäntti et al. 2011). It is accordingly possible that similar development (i.e., increase in $\mathrm{NO}_{x}$ and decrease in $\mathrm{NH}_{4}{ }^{+}$concentration) for $\mathrm{NH}_{4}{ }^{+}$or $\mathrm{NO}_{x}$ fluxes as in Niemistö et al. (2018) could have been observed in this study, provided that concentrations were measured for a longer time period following the resuspension.

Nitrifying bacteria requires oxygen and $\mathrm{NH}_{4}{ }^{+}$to produce $\mathrm{NO}_{x}$ (Thamdrup and Dalsgaard 2008; Jäntti et al. 2011). In the studied area, the highest nitrification potential has been observed in spring during high oxygen supply, but the highest nitrification rates has been measured in summer when the $\mathrm{NH}_{4}{ }^{+}$supply is at its greatest (Jäntti et al. 2011). These prerequisites and the background knowledge of nitrification rates in the study area suggest that the highest $\mathrm{NO}_{x}$ fluxes in our experiments should have been observed in August. Since the highest instantaneous $\mathrm{NO}_{x}$ fluxes were measured in May, it is obvious that locally nitrification can be intensive also during spring providing that the supply of $\mathrm{NH}_{4}{ }^{+}$is high, as was the case in the two most organic stations 3 and 4 .

The results of the present study demonstrated the instantaneous effects of resuspension on the benthic $\mathrm{NH}_{4}{ }^{+}$and $\mathrm{NO}_{x}$ fluxes. However, it is worth noticing that resuspension may contribute to different nitrogen transformation pathways and thereby to benthic fluxes of different nitrogen species also in the longer term. For instance, by introducing more oxygen in the surface sediment, resuspension may decrease $\mathrm{NH}_{4}{ }^{+}$fluxes by promoting nitrification as has been observed in the studied area by Niemistö et al. (2018), and also shown in other studies (Spagnoli and Bergamini 1997; Almroth-Rosell et al. 2012).
This in turn could be expected to enhance the subsequent denitrification that depends on the supply of $\mathrm{NO}_{x}$ (Thamdrup and Dalsgaard 2008).

\section{Resuspension-Induced DSi Fluxes}

The resuspension-induced DSi fluxes were from 1 to 2 orders of magnitude higher than the SWI-diffusive fluxes of the present study or the diffusive fluxes presented by the other studies conducted in the same area (Villnäs et al. 2013; Tallberg et al. 2017; Niemistö et al. 2018). Our results showed the importance of resuspension for the sediment-water cycling of Si in the study area, and is in concordance with the previous studies that have shown the stimulation of desorptive fluxes by resuspension, and the subsequent exposure of sediment particles to variation in pore water concentrations (e.g., Rutgers van der Loeff et al. 1984; Shum 1993; Gehlen and Van Raaphorst 2002), The present instantly induced (10-min treatment + 10-min slow stirring) DSi fluxes were high compared with the previous study conducted on longer time scales (12-70 h) in GoF (Almroth et al. 2009; Niemistö et al. 2018). In fact, the longer time scale treatments resulted in the decrease of the benthic DSi flux (Almroth et al. 2009; Niemistö et al. 2018). On the other hand, high increase in the concentration of DSi has been observed after the initiation of a strong resuspension treatment from other marine areas (Almroth-Rosell et al. 2012). Here, a 2 -fold concentration increase compared with that was found. However, the $2 \times \tau_{\text {crit }}$ current velocities applied in the present resuspension treatments are commonly observed in the study area during upwelling events in spring and summer (Haapala 1994). This suggests that the treatment was of a relevant magnitude to study resuspension-induced benthic fluxes.

The resuspension-induced high pulse of DSi as a first rapid response in the present study and the decrease in the benthic DSi flux during a longer experiment periods found by other studies (Almroth et al. 2009; Niemistö et al. 2018) are not contradictive, but rather present the normal desorptionadsorption reactions of DSi in the case of sediment surface disturbance. After initiation of resuspension, surface sediment particles are mixed to the near-bottom water with lower DSi concentration than in the pore water, which may lead to desorption of Si from particle surfaces (e.g., Gehlen and Van Raaphorst 2002). In addition to this, DSi is readily in a dissolved form in the pore water and can be transported up into the near-bottom water. On the other hand, also pore water $\mathrm{DFe}$ will be introduced to near-bottom water and in the oxygenated conditions, as in the present study, new Fe-oxyhydroxides will form and as effective adsorbents for DSi (Sigg and Stumm 1981; Anderson and Benjamin 1985), these substances may decrease the benthic DSi flux (Almroth et al. 2009; AlmrothRosell et al. 2012; Niemistö et al. 2018). The latter is likely to be observed in longer time scale incubations, although the 
formation of Fe-oxyhydroxides and subsequent adsorption of DSi can occur in time scales of minutes (Wang and Van Cappellen 1996; Gehlen and Van Raaphorst 2002).

The adsorption of DSi onto newly formed Feoxyhydroxides would explain the high variation in the DSi concentration increments between the replicates (even a decrease observed in few replicates) that resulted in nonsignificant fluxes for some stations. The fact that the highest DSi fluxes were observed at stations 4 (in Aug and May) and 3 (in May), where the DFe:DSi ratios were lowest, corroborates this theory. Additionally, benthic animals can strongly affect DSi fluxes (Rutgers van der Loeff et al. 1984; Bonaglia et al. 2013). The two benthic macrofaunal taxa Macoma balthica and Marezelleria spp. that showed the highest densities among all the determined species in the experimental columns of the present study are known to affect the benthic nutrient fluxes in the study area (Kauppi et al. 2017). In general, the nutrient effluxes are increased with the increasing density of fauna and increasing organic content of the sediment (Kauppi et al. 2017), which is likely due to enhanced mineralization of organic material by fauna activity (Ståhl et al. 2004). The highest mean densities ( \pm SD) of Marezelleria spp. (902 \pm 255 ind. $\mathrm{m}^{-2}$ in May vs $2256 \pm 938$ ind. $\mathrm{m}^{-2}$ in Aug) and Macoma balthica $\left(1038 \pm 497\right.$ ind. $\mathrm{m}^{-2}$ in May vs $5188 \pm$ 1066 ind. $\mathrm{m}^{-2}$ in Aug) were found from the most organic stations 3 and 4, respectively. Accordingly, the highest resuspension-induced DSi fluxes were recorded in stations 3 and 4 in May and in station 4 in August. Thus, the fluxes seemed to be increased by the interplay of high abundance of fauna and high organic content of the surface sediment. Additionally, in station 4, the increase in the abundance of Macoma balthica during summer most likely contributed to the seasonal difference observed in the resuspension-induced DSi flux. Finally, the highest flux being measured in August is in concordance with the earlier findings that benthic DSi effluxes have shown positive temperature dependence (e.g., Lewin 1961) and tend to peak late in summer due to the slow initial dissolution of the $\mathrm{Si}$ frustules formed in the diatom spring bloom (Tallberg et al. 2013).

\section{Resuspension-Induced DIP Fluxes}

Statistically significant resuspension-induced DIP fluxes were recorded only at stations 3 and 4 in May. These fluxes were of similar level to the benthic fluxes measured from undisturbed anoxic bottoms and approximately 10-fold to the fluxes measured from the oxic undisturbed bottoms in the GoF (Viktorsson et al. 2012). Therefore, it can be stated that occasionally resuspension events can induce marked benthic DIP fluxes from the organic rich bottoms of the study area. The fact that the significant fluxes were recorded only in two out of eight experiments (all experiments in May and August considered) was most likely associated with the high DFe:DIP ratios of the surface sediment. The molar ratios that apart from station 4 showed values above 2 being an indication of strong P-binding capacity of the surface sediment under the prevailing oxic conditions (Gunnars and Blomqvist 1997). Accordingly, the stations ( 3 and 4 ) that showed the statistically significant DIP fluxes due to resuspension had the lowest DFe:DIP ratios in the surface sediments.

The oxidation of soluble iron and the subsequent precipitation of phosphates can occur in time scales of seconds (Wang and Van Cappellen 1996). Thus, it was expected that in the time scale of the resuspension treatment, 10-min resuspension +10 -min slow stirring, DIP mixed into to near-bottom water would already be precipitated with newly produced iron oxyhydroxides. As stated above, apart from the two most organic rich study sites that showed a high benthic flux of DIP due to treatment in May, this seemed to be the case. However, on a longer time scale, phosphates bound to particles may be released again at the same location, since resuspension can increase the benthic oxygen consumption (Almroth-Rosell et al. 2012; Niemistö et al. 2018). Additionally, the phosphorus-rich particles may be transported to areas suffering from hypoxia and be released there.

\section{Resuspension-Induced Fluxes of Dissolved Organic Nutrients}

Studies on benthic fluxes of dissolved organic nutrients in the Baltic Sea sediments (Ekeroth et al. 2016) or even the nearby areas as the Danish Straits (Ståhl et al. 2004) are sparse. Thus, the diffusive fluxes presented here are valuable novel results. Additionally, to the best of our knowledge, the present study is the first to provide benthic fluxes of dissolved organic nutrients induced by known current velocities. Here, resuspensioninduced fluxes for DOC and DOP were detected only in a few experiments, and as in the case of other nutrients, these were several times higher compared with the SWI-diffusive fluxes or to the fluxes detected in the control columns. The SWI fluxes for DON and DOP were, however, comparable to diffusive fluxes observed in Baltic Sea sediments Ekeroth et al. (2016). The SWI-diffusive fluxes of DOC were comparable to fluxes measured in Danish Straits (Ståhl et al. 2004) and at the lower limits of fluxes observed from other shallow coastal and estuarine areas by whole core laboratory incubations (e.g., Burdige and Homstead 1994) or by benthic chamber measurements (e.g., Skoog et al. 1996; Burdige et al. 1999). The only statistically significant flux of DOC observed in the control columns for the high organic content station 4 in August was two orders of magnitude higher than the SWI fluxes and at the similar level as observed from coastal sediments after anoxic treatment (Skoog and Arias-Esquivel 2009).

In most of the experiments, resuspension treatment caused no detectable fluxes of dissolved organic nutrients (e.g., no effects on DON). Most likely, as was the case for DIP and $\mathrm{DSi}$, this was associated with the formation of oxyhydroxides due to oxidation of sedimentary DFe, and subsequent 
coprecipitation of organic dissolved molecules that were simultaneously mixed to near-bottom water during resuspension. Iron oxides are known to effectively adsorb organic compounds (Balistrieri and Murray 1987; Skoog and AriasEsquivel 2009). High effluxes of DOC were observed at stations 2 and 4 . Station 4 was the most organic and had the lowest DFe concentration of pore water in the surface sediment of the four stations, which would explain this result. Station 2 in turn, showed the highest DFe concentration of the pore water of all the stations. Thus, the detected DOC flux could simply result from the heterogeneity of the sediment at this location and the treated sediments could have been collected from an organic rich spot. The fact that the second highest $\mathrm{NH}_{4}{ }^{+}$flux of all experiments was measured from the same station supports this conclusion. In general, the DOC fluxes and high $\mathrm{NH}_{4}{ }^{+}$fluxes being observed in August are in concordance with the previous knowledge as also mentioned above that the activity of heterotrophic bacteria is at its highest in summer (Vetterli et al. 2015). Additionally, the mineralization rate of organic matter in the sediment is known to positively correlate with the benthic DOC-efflux (Ståhl et al. 2004).

As in the case of other redox-dependent nutrients, the adsorption of dissolved organic nutrients on Fe-oxyhydroxides may affect their transport to the deeper areas. Thus, if transported to hypoxic or anoxic bottoms, they can be liberated back to the water column (Ståhl et al. 2004; Skoog and Arias-Esquivel 2009). On the other hand, some of the benthic organic nutrients that stay in the dissolved form in the water column after resuspension-induced transport may be readily, or after exoentsymatic hydrolysis, available for phytoplankton (Berman and Bronk 2003; See et al. 2006; Korth et al. 2012). Both particulate and dissolved organic nutrients of sedimentary origin may also be a source of important main nutrients for primary production, ammonium and phosphate, after being exposed to solar irradiation (Mayer et al. 2006; Kieber et al. 2006; Southwell et al. 2010). Additionally, resuspension-enhanced mineralization of benthic organic matter intensifies nutrient recycling into water column (e.g., Sloth et al. 1996; Ståhlberg et al. 2006). Thus, the foreseen more frequent and stronger resuspension events may contribute to internal nutrient loading of shallow coastal areas also via increased heterotrophic mineralization and photodegradation of benthic organic nutrients.

\section{Conclusions}

Resuspension treatment $\left(2 \times \tau_{\text {crit }}\right)$ increased the concentrations of the studied nutrients approximately in half of the experiments in May and August. The resuspension-induced benthic effluxes of nutrients were from one to two orders of magnitude higher than the fluxes measured in the control columns of the experiments or the diffusive fluxes based on the concentration gradient between the pore waters of the surface sediment and near-bottom water. The effluxes quantitatively connected to known current velocities, which are novel knowledge in this respect and in the Gulf of Finland, were mainly detected for $\mathrm{NH}_{4}{ }^{+}, \mathrm{NO}_{x}$, and $\mathrm{DSi}$, but marked effluxes were measured also for DIP, DOP, and DOC in a few experiments.

Mineralization of organic material increased the pore water concentrations of nutrients on the course of the growth season and resulted in high resuspension-induced effluxes especially at the organic rich stations in August. In addition to the heterogeneity of the studied sediments, the precipitation/adsorption of redox-dependent nutrients, DIP, DSi, and dissolved organic nutrients, onto newly formed iron oxyhydroxides were the most likely reasons for the result that the resuspension-induced effluxes were not consistently observed in all of the experiments. This was evidenced by the highest effluxes being measured for the stations with the lowest $\mathrm{DFe}$ concentrations in the pore water. High $\mathrm{NH}_{4}{ }^{+}$and $\mathrm{NO}_{x}$ effluxes were attributed to the high organic content of sediments, but in the case of $\mathrm{NO}_{x}$ also to the high supply of oxygen, and thus the highest effluxes were measured in spring.

According to the near-bottom current velocity recordings, the critical shear velocities and the current velocities applied in the experiments were infrequently exceeded over the periods of nutrient flux experiments. However, the climate change will result in stronger and more frequent resuspension events and thus most likely enhance the cycling and internal loading of nutrients in the shallow coastal areas of the Baltic Sea as in other similar marine areas. The benthic nutrient effluxes reported here were induced with known forces and current velocities and may thus be utilized in modeling approaches aiming at assessing the internal nutrient loading and the levels of external loading reductions that will be needed to minimize the effects of eutrophication in the Baltic Sea in a changing climate.

Acknowledgments The authors want to thank the following persons for the help at the field and in the laboratory: Niklas Virkkala, Maria Arola, Jani Ruohola, Soila Silvonen, and Laboratory and Field personnel of the Tvärminne Zoological Station.

Funding Information Open access funding provided by University of Helsinki including Helsinki University Central Hospital. This work was supported by the Maj and Tor Nessling Foundation (grant numbers: 201300036, 201400009, 201500252).

Open Access This article is distributed under the terms of the Creative Commons Attribution 4.0 International License (http:// creativecommons.org/licenses/by/4.0/), which permits unrestricted use, distribution, and reproduction in any medium, provided you give appropriate credit to the original author(s) and the source, provide a link to the Creative Commons license, and indicate if changes were made. 


\section{References}

Almroth, E., A. Tengberg, J.H. Andersson, S. Pakhomova, and P.O.J. Hall. 2009. Effects of resuspension on benthic fluxes of oxygen, nutrients, dissolved inorganic carbon, iron and manganese in the Gulf of Finland, Baltic Sea. Continental Shelf Research 29: 807818.

Almroth-Rosell, E., A. Tengberg, S. Andersson, A. Apler, and P.O.J. Hall. 2012. Effects of simulated natural and massive resuspension on benthic oxygen, nutrient and dissolved inorganic carbon fluxes in Loch Creran, Scotland. Journal of Sea Research 72: 38-48.

Andersen, J.H., J. Carstensen, D.J. Conley, K. Dromph, V. FlemingLehtinen, B.G. Gustafsson, A.B. Josefson, A. Norkko, A. Villnäs, and C. Murray. 2015. Long-term temporal and spatial trends in eutrophication status of the Baltic Sea. Biological Reviews 92: 135-149. https://doi.org/10.1111/brv.12221.

Anderson, P.R., and M.M. Benjamin. 1985. Effects of silicon crystallization and adsorption properties of ferric oxides. Environmental Science \& Technology 19: 1048-1053.

Asmala, E., D.G. Bowers, R. Autio, H. Kaartokallio, and D.N. Thomas. 2014. Qualitative changes of riverine dissolved organic matter at low salinities due to flocculation. Journal of Geophysical Research - Biogeosciences 119: 1919-1933. https://doi.org/10. 1002/2014JG002722.

Balistrieri, L.S., and J.W. Murray. 1987. The influence of the major ions of seawater on the adsorption of simple organic acids by goethite. Geochimica et Cosmochimica Acta 51: 1151-1160.

Barbanti, A., V.U. Ceccherelli, F. Frascari, G. Reggiani, and G. Rosso. 1992. Nutrient regeneration processes in bottom sediments in a Po delta lagoon (Italy) and the role of bioturbation on determining the fluxes at the sediment-water interface. Hydrobiologia 228: 1-21.

Berelson, W.M., W.Z. Haskell, M. Prokopenko, A.N. Knapp, D.E. Hammond, N. Rollins, and D.G. Capone. 2015. Biogenic particle flux and benthic remineralization in the Eastern Tropical South Pacific. Deep-Sea Research Part I 99: 23-34.

Berman, T., and D.A. Bronk. 2003. Dissolved organic nitrogen: A dynamic participant in aquatic ecosystems. Aquatic Microbial Ecology 31: 279-305.

Berner, R.A. 1980. Early diagenesis: A theoretical approach (No. 1). Princeton University Press.

Bonaglia, S., M. Bartoli, J.S. Gunnarsson, L. Rahm, C. Raymond, O. Svensson, S. Shakeri Yekta, and V. Brüchert. 2013. Effect of reoxygenation and Marenzelleria spp. bioturbation on Baltic Sea sediment metabolism. Marine Ecology Progress Series 482: 43-55.

Boudreau, B.P., ed. 1996. Diagenetic models and their implementation: Modelling transport and reaction in aquatic sediments. Berlin, Heidelberg, New York: Springer.

Boynton, W.R., M.A.C. Ceballos, E.M. Bailey, C.L.S. Hodgkins, J.L. Humphrey, and J.M. Testa. 2018. Oxygen and nutrient exchanges at the sediment-water interface: a global synthesis and critique of estuarine and coastal data. Estuaries and Coasts 41: 301-333. https://doi.org/10.1007/s12237-017-0275-5.

Burdige, D.J., and J. Homstead. 1994. Fluxes of dissolved organic carbon from Chesapeake Bay sediments. Geochimica et Cosmochimica Acta 58: 3407-3424.

Burdige, D.J., M.J. Alperin, J. Homstead, and C.S. Martins. 1992. The role of benthic fluxes of dissolved organic carbon in oceanic and sedimentary carbon cycling. Geophysical Research Letters 19: 1851-1854.

Burdige, D.J., W.M. Berelson, K.H. Coale, J. McManus, and K.S. Johnson. 1999. Fluxes of dissolved organic carbon from California continental margin sediments. Geochimica et Cosmochimica Acta 63: $1507-1515$.

Capet, A., F.J.R. Meysman, I. Akoumianaki, K. Soetaert, and M. Grégoire. 2016. Integrating sediment biogeochemistry into 3D oceanic models: A study of benthic-pelagic coupling in the Black Sea. Ocean Modelling 101: 83-100.

Christiansen, C., and E. Emelyanov. 1995. Nutrients and organic matter in recent southern Kattegat-Baltic Sea sediments: Consequences of resuspension. Geografisk Tidsskrift 95: 19-27.

Christiansen, C., I. Zacharias, and T. Vang. 1992. Storage, redistribution and net export of dissolved and sedimentbound nutrients, Vejle Fjord, Denmark. Hydrobiologia 235 (236): 47-57.

Christiansen, C., K. Edelvang, K. Emeis, G. Graf, S. Jähmlich, J. Kozuch, M. Laima, T. Leipe, A. Löffler, L.C. Lund-Hansen, A. Miltner, K. Pazdro, J. Pempkowiak, G. Shimmield, T. Shimmield, J. Smith, M. Voss, and G. Witt. 2002. Material transport from the nearshore to the basinal environment in the southern Baltic Sea I. Processes and mass estimates. Journal of Marine Systems 35: 133-150.

Clavero, V., J.A. Fernández, and F.X. Niell. 1992. Bioturbation by Nereis sp. and its effects on the phosphate flux across the sediment-water interface in Palmones River estuary. Hydrobiologia 235: 387-392.

Danielsson, Å., A. Jönsson, and L. Rahm. 2007. Resuspension patterns in the Baltic proper. Journal of Sea Research 57: 257-269.

Davis, W.R. 1993. The role of bioturbation in sediment resuspension and its interaction with physical shearing. Journal of Experimental Marine Biology and Ecology 171: 187-200.

Dzombak, D., and F.M.M. Morel. 1990. Surface complexation modeling: Hydrous ferric oxide. New York, U.S.A.: Wiley.

Ekeroth, N., S. Blomqvist, and P.O.J. Hall. 2016. Nutrient fluxes from reduced Baltic Sea sediment: effects of oxygenation and macrobenthos. Marine Ecology Progress Series 544: 77-92.

Eusterhues, K., F.E. Wagner, W. Haeusler, M. Hanzlik, H. Knicker, K.U. Totsche, I. Koegel-Knabner, and U. Schwertmann. 2008. Characterization of ferrihydrite-soil organic matter coprecipitates by X-ray diffraction and Mössbauer spectroscopy. Environmental Science \& Technology 42: 7891-7897. https://doi.org/10.1021/ es $800881 \mathrm{w}$.

Fanning, K.A., K.L. Carder, and P.R. Betzer. 1982. Sediment resuspension by coastal waters: A potential mechanism for nutrient recycling on the ocean's margins. Deep Sea Research 29 (8): 953-965.

Floderus, S., and L. Håkanson. 1989. Resuspension, ephemeral mud blankets and nitrogen cycling in Laholmsbukten, south east Kattegat. Hydrobiologia 176 (177): 61-75.

Gehlen, M., and W. Van Raaphorst. 2002. The role of adsorptiondesorption surface reactions in controlling interstitial $\mathrm{Si}(\mathrm{OH})_{4}$ concentrations and enhancing $\mathrm{Si}(\mathrm{OH})_{4}$ turn-over in shallow shelf seas. Continental Shelf Research 22: 1529-1547.

Gunnars, A., and S. Blomqvist. 1997. Phosphate exchange across the sediment-water interface when shifting from anoxic to oxic conditions-an experimental comparison of freshwater and brackish-marine systems. Biogeochemistry 37: 203-226.

Haapala, J. 1994. Upwelling and its influence on nutrient concentration in the coastal area of the Hanko Peninsula, entrance of the Gulf of Finland. Estuarine, Coastal and Shelf Science 3: 507-521.

Heiskanen, A.-S., J. Haapala, and K. Gundersen. 1998. Sedimentation and pelagic retention of particulate $\mathrm{C}, \mathrm{N}$ and $\mathrm{P}$ in the coastal northern Baltic Sea. Estuarine, Coastal and Shelf Science 46: 703-712.

Huttunen, I., H. Lehtonen, M. Huttunen, V. Piirainen, M. Korppoo, N. Veijalainen, M. Viitasalo, and B. Vehviläinen. 2015. Effects of climate change and agricultural adaptation on nutrient loading from Finnish catchments to the Baltic Sea. Science of the Total Environment 529: 168-181.

Jäntti, H., C.F. Stange, E. Leskinen, and S. Hietanen. 2011. Seasonal variation in nitrification and nitrate-reduction pathways in coastal sediments in the Gulf of Finland, Baltic Sea. Aquatic Microbial Ecology 63: 171-181.

Jilbert, T., E. Asmala, C. Schröder, R. Tiihonen, J.-P. Myllykangas, J.J. Virtasalo, A. Kotilainen, P. Peltola, P. Ekholm, and S. Hietanen. 2017. Flocculation of dissolved organic matter controls the 
distribution of iron in boreal estuarine sediments. Biogeosciences Discussions. https://doi.org/10.5194/bg-2017-181.

Jönsson, A. 2005. Model studies of surface waves and sediment resuspension in the Baltic Sea. Ph.D. thesis, Department of Water and Environmental Studies, Linköping University. Linköping Studies in Arts and Science, No. 332.

Kauppi, L., J. Norkko, J. Ikonen, and A. Norkko. 2017. Seasonal variability in ecosystem functions: Quantifying the contribution of invasive species to nutrient cycling in coastal ecosystems. Marine Ecology Progress Series 572: 193-207.

Kieber, R.J., R.F. Whitehead, and S.A. Skrabal. 2006. Photochemical production of dissolved organic carbon from resuspended sediments. Limnology and Oceanography 51: 2187-2195.

Koroleff, F. 1983. Determination of nutrients. In Methods of sea water analysis, ed. K. Grasshoff, M. Ehrhardt, and K. Kremling. Weinheim: Wiley-VCH.

Korth, F., B. Deutsch, I. Liskow, and M. Voss. 2012. Uptake of dissolved organic nitrogen by size-fractionated plankton along a salinity gradient from the North Sea to the Baltic Sea. Biogeochemistry 111: 347-360.

Koski-Vähälä, J., and H. Hartikainen. 2000. Resuspended sediment as a source and sink for soluble phosphorus. Verhand des InternationalenVerein Limnologie 27: 1-7.

Krom, M.D., and R.A. Berner. 1980. The diffusion coefficients of sulfate, ammonium, and phosphate ions in anoxic marine sediments. Limnology and Oceanography 25 (2): 327-337.

Lewin, J.C. 1961. The dissolution of silica from diatom walls. Geochimica et Cosmochimica Acta 21: 182-198.

Li, Y.-H., and S. Gregory. 1974. Diffusion of ions in sea water and in deep-sea sediments. Geochimica et Cosmochimica Acta 38: 708714.

Lund-Hansen, L.C., J. Valeur, M. Pejrup, and A. Jensen. 1997. Sediment fluxes, re-suspension and accumulation rates at two wind-exposed coastal sites and in a sheltered bay. Estuarine, Coastal and Shelf Science 44: 521-531.

Lund-Hansen, L.C., C. Christiansen, O. Jensen, and M. Laima. 1999. The LABEREX chamber for studying the critical shear stress for fine grained sediment. Geografisk Tidsskrift, Danish Journal of Geography 99: 1-7.

Lund-Hansen, L.C., M. Laima, K. Mouritsen, N.N. Lam, and D.N. Hai. 2002. Effects of benthic diatoms, fluff layer, and sediment conditions on critical shear stress in a non-tidal coastal environment. Journal of the Marine Biological Association of the United Kingdom 82: 929-936.

Mayer, L.M., L.L. Schick, S. Krysia, and E. Boss. 2006. Photodissolution of particulate organic matter from sediments. Limnology and Oceanography 51: 1064-1071.

Moriarty, J.M., C.K. Harris, K. Fennel, M.A.M. Friedrichs, K. Xu, and C. Rabouille. 2017. The roles of resuspension, diffusion and biogeochemical processes on oxygen dynamics offshore of the Rhône River, France: a numerical modeling study. Biogeosciences 14: 1919-1946.

Morin, J., and J.W. Morse. 1999. Ammonium release from resuspended sediments in the Laguna Madre estuary. Marine Chemistry 65 (1-2): $97-110$

Niemi, A. 1975. Ecology of phytoplankton in the Tvärminne area SW coast of Finland. II. Primary production and conditions in the archipelago zone and sea zone. Acta Botanica Fennica 105: 1-73.

Niemistö, J., M. Kononets, N. Ekeroth, P. Tallberg, A. Tengberg, and P.O.J. Hall. 2018. Benthic fluxes of oxygen and inorganic nutrients in the archipelago of Gulf of Finland, Baltic Sea - Effects of sediment resuspension measured in situ. Journal of Sea Research 135: 95-106.

Pant, H.K., and K.R. Reddy. 2001. Phosphorus sorption characteristics of estuarine sediments under different redox conditions. Journal of Environmental Quality 30: 1474-1480.
Porter, E.T., R.P. Mason, and L.P. Sanford. 2010. Effect of tidal resuspension on benthic-pelagic coupling in an experimental ecosystem study. Marine Ecology Progress Series 413: 33-53.

Räisänen, J., U. Hansson, A. Ullerstig, R. Döscher, L.P. Graham, C. Jones, H.E.M. Meier, P. Samuelsson, and U. Willén. 2004. European climate in the late twenty-first century: regional simulations with two driving global models and two forcing scenarios. Climate Dynamics 22: 13-31.

Reddy, K.R., M.M. Fisher, and D. Ivanoff. 1996. Resuspension and diffusive flux of nitrogen and phosphorus in a hypereutrophic lake. Journal of Environmental Quality 25 (2): 363-371.

Renberg, I., and H. Hansson. 2008. The HTH sediment corer. Journal of Paleolimnology 40: 655-659.

Rutgers van der Loeff, M., L.G. Anderson, P.O.J. Hall, Å. Iverfeldt, A. Josefson, B. Sundby, and S. Westerlund. 1984. The asphyxiation technique: an approach to distinguishing between molecular diffusion and biologically mediated transport at the sediment-water interface. Limnology and Oceanography 29: 675-686.

Sarazin, G., J.-F. Gaillard, L. Philippe, and C. Rabouille. 1995. Organic matter mineralisation in the pore water of a eutrophic lake (Aydat Lake, Puy de Dôme, France). Hydrobiologia 315: 95-118.

SAS Institute Inc. 2008. SAS OnlineDoc, Version 8. Cary NC: SAS Institute Inc.

Schneider, C., C.L.R. Laizé, M.C. Acreman, and M. Florke. 2013. How will climate change modify river flow regimes in Europe? Hydrology and Earth System Sciences 17 (1): 325-339.

Schulz, H.D. 2006. Quantification of early diagenesis: dissolved constituents in pore water and signals in the solid phase. In Marine geochemistry, ed. H.D. Schulz and M. Zabel, 2nd ed., 73-124. Berlin Heidelberg: Springer-Verlag.

See, J.H., D.A. Bronk, and A.J. Lewitus. 2006. Uptake of Spartinaderived humic nitrogen by estuarine phytoplankton in nonaxenic and axenic culture. Limnology and Oceanography 51: 2290-2299.

Seeberg-Elverfeldt, J., M. Schlüter, T. Feseker, and M. Kölling. 2005. Rhizon sampling of porewaters near the sediment-water interface of aquatic systems. Limnology and Oceanography: Methods 3: 361-371.

Sheng, Y.P., and W. Lick. 1979. The transport and resuspension of sediments in a shallow lake. Journal of Geophysical Research 84: 18091826.

Shum, K.T. 1993. The effects of wave-induced pore water circulation on the transport of reactive solutes below a rippled sediment bed. Journal of Geophysical Research 98 (C6): 10289-10301.

Sigg, L., and W. Stumm. 1981. The interaction of anions and weak acids with the hydrous goethite $(\alpha-\mathrm{FeOOH})$ surface. Colloids and Surfaces 2: 101-117.

Skoog, A.C., and V.A. Arias-Esquivel. 2009. The effect of induced anoxia and reoxygenation on benthic fluxes of organic carbon, phosphate, iron, and manganese. Science of the Total Environment 407: 6085-6092.

Skoog, A.C., P.O.J. Hall, S. Hulth, N. Paxeus, M.M. Rutgers van der Loeff, and S. Westerlund. 1996. Early diagenetic production of fluorescent organic matter in the coastal environment. Geochimica et Cosmochimica Acta 60: 3619-3629.

Sloth, N.P., B. Riemann, L.P. Nielsen, and T.H. Blackburn. 1996. Resilience of pelagic and benthic microbial communities to sediment resuspension in a coastal ecosystem, Knebel Vig, Denmark. Estuarine, Coastal and Shelf Science 42: 405-415.

Solórzano, L. 1969. Determination of ammonia in natural waters by the phenolhypochlorite method. Limnology and Oceanography 14: 799-801.

Solórzano, L., and J.H. Sharp. 1980. Determination of total dissolved phosphorus and particulate phosphorus in natural waters1. Limnology and Oceanography 25 (4): 754-758.

Southwell, M.W., R.J. Kieber, R.N. Mead, G.B. Avery, and S.A. Skrabal. 2010. Effects of sunlight on the production of dissolved organic and 
inorganic nutrients from resuspended sediments. Biogeochemistry 98: 115-126.

Spagnoli, F., and M.C. Bergamini. 1997. Water-sediment exchange of nutrients during early diagenesis and resuspension of anoxic sediments from the Northern Adriatic Sea shelf. Water, Air, and Soil Pollution 99 (1-4): 541-556.

Ståhl, H., A. Tengberg, J. Brunnegård, E. Bjørnbom, and P.O.J. Hall. 2004. Factors influencing organic carbon recycling and burial in Skagerrak sediments. Journal of Marine Research 62: 867-907.

Ståhlberg, C., D. Bastviken, B.H. Svensson, and L. Rahm. 2006. Mineralisation of organic matter in coastal sediments at different frequency and duration of resuspension. Estuarine, Coastal and Shelf Science 70: 317-325.

Sundby, B., L.G. Anderson, P.O.J. Hall, Å. Iverfeldt, M.M. Rutger van der Loeff, and S.F.G. Westerlund. 1986. The effect of oxygen on release and uptake of cobalt, manganese, iron and phosphate at the sediment-water interface. Geochimica et Cosmochimica Acta 50: $1281-1288$.

Tallberg, P., P. Tréuger, C. Beucher, and R. Corvaisier. 2008. Potentially mobile pools of phosphorus and silicon in sediment from the bay of Brest: interactions and implications for phosphorus dynamics. Estuarine, Coastal and Shelf Science 76: 85-94.

Tallberg, P., J. Lehtoranta, and S. Hietanen. 2013. Silicate release from sand-manipulated sediment cores: biogenic or adsorbed $\mathrm{Si}$ ? SILICON 5: 67-74.

Tallberg, P., A.-S. Heiskanen, J. Niemistö, P.O.J. Hall, and J. Lehtoranta. 2017. Are benthic fluxes important for the availability of $\mathrm{Si}$ in the Gulf of Finland? Journal of Marine Systems. https://doi.org/10. 1016/j.jmarsys.2017.01.010.

Tengberg, A., P.O.J. Hall, U. Andersson, B. Lindén, O. Styrenius, G. Boland, F. de Bovee, B. Carlsson, S. Ceradini, A. Devol, G. Duineveld, J.-U. Friemann, R.N. Glud, A. Khripounoff, J. Leather, P. Linke, L. Lund-Hansen, G. Rowe, P. Santschi, P. de Wilde, and U.
Witte. 2005. Intercalibration of benthic flux chambers II. Hydrodynamic characterization and flux comparisons of 14 different designs. Marine Chemistry 94: 147-173.

Thamdrup, B., and T. Dalsgaard. 2008. Nitrogen cycling in sediments. In Microbial ecology of the oceans, ed. D.L. Kirchman, 2nd ed., 527568. Hoboken New Jersey: Wiley.

Thomsen, L., T. van Weering, and G. Gust. 2002. Processes in the benthic boundary layer at the Iberian continental margin and their implication for carbon mineralization. Progress in Oceanography 52 (2-4): 315-329.

Vetterli, A., K. Hyytiäinen, M. Ahjos, P. Auvinen, L. Paulin, S. Hietanen, and E. Leskinen. 2015. Seasonal patterns of bacterial communities in the coastal brackish sediments of the Gulf of Finland, Baltic Sea. Estuarine, Coastal and Shelf Science 165: 86-96.

Viktorsson, L., E. Almroth-Rosell, A. Tengberg, R. Vankevich, I. Neelov, A. Isaev, V. Kravtsov, and P.O.J. Hall. 2012. Benthic phosphorus dynamics in the Gulf of Finland, Baltic Sea. Aquatic Geochemistry 18: 543-564. https://doi.org/10.1007/s10498-011-9155-y.

Villnäs, A., J. Norkko, S. Hietanen, A.B. Josefson, K. Lukkari, and A. Norkko. 2013. The role of recurrent disturbances for ecosystem multifunctionality. Ecology 94: 2275-2287.

Virtasalo, J., T. Kohonen, I. Vuorinen, and T. Huttula. 2005. Sea bottom anoxia in the Archipelago Sea, northern Baltic Sea - Implications for phosphorus remineralization at the sediment surface. Marine Geology 224: 103-122,10. https://doi.org/10.1016/j.margeo.2005. 07.010 .

Wang, Y., and P. Van Cappellen. 1996. A multicomponent reactive transport model of early diagenesis: Application to redox cycling in coastal marine sediments. Geochimica et Cosmochimica Acta 60: 2993-3014. https://doi.org/10.1016/0016-7037(96)00140-8.

Winterhalter, B., T. Flodén, H. Ignatius, S. Axberg, and L. Niemistö. 1981. Geology of the Baltic Sea. In The Baltic Sea, ed. A. Voipio. Amsterdam, The Netherlands: Elsevier. 